\title{
Estructura de la comunidad bacteriana en diferentes tejidos de Lobatus gigas silvestres (Linnaeus, 1758) de la Reserva de Biosfera Seaflower del Caribe
}

\author{
Bacterial community structure in different tissues of the wild Lobatus gigas \\ (Linnaeus, 1758) from the Caribbean Seaflower Biosphera Reserve
}

\author{
Mónica Marcela Higuita-Valencia, Olga Inés Montoya Campuzano, Edna Judith Márquez Fernández and Claudia Ximena Moreno Herrera \\ (iD) OrcID: 0000-0002-4031-493 \\ (iD) 0000-0002-4820-0381 \\ (iD) 0000-0003-0760-3747 \\ (iD) 0000-0002-8132-5223
}

Facultad de Ciencias, Universidad Nacional de Colombia, sede Medellín, Colombia. Grupo de Microbiodiversidad y Bioprospección (Microbiop), Universidad Nacional de Colombia-Sede Medellín-Facultad de Ciencias-Escuela de Biociencias-Laboratorio de Biología Celular y Molecular, Calle 59A No 63 - 20 Bloque 19 A Laboratorio 310,Medellín,050034Colombia.Email: cxmoreno@unal.edu.co; mmhiguit@unal.edu.co,oimontoy@unal.edu.co, ejmarque@unal.edu.co.

\section{RESUMEN}

$\mathrm{L}$ a diversidad microbiana de Lobatus gigas no se ha estudiado a fondo a pesar de que se trata de una especie en peligro de extinción. El conocimiento de la microbiota puede ayudar a mejorar la conservación y el cultivo de esta especie. El objetivo de este estudio fue evaluar

las poblaciones bacterianas asociadas con la gónada y en los compartimentos intestinales de L. gigas en peligro de extinción de la Reserva de la Biosfera Seaflower del Caribe, utilizando métodos microbiológicos y herramientas moleculares independientes del cultivo. Se generaron los perfiles genéticos de las poblaciones bacterianas y se utilizó la Electroforesis Gradual de Gradiente de Temperatura (TTGE) para compararlos con el ADN total. Un análisis genético y estadístico de las comunidades bacterianas reveló un bajo nivel de diversidad en el tejido de las gónadas en función del número de bandas detectadas mediante TTGE. Además, se encontraron diferencias estadísticas en la estructura de la comunidad bacteriana entre el intestino anterior y el tejido del intestino posterior de L. gigas. Las afiliaciones filogenéticas dominantes de las bacterias en la gónada, según se determinó usando la secuenciación del gen RNAr $16 \mathrm{~S}$, pertenecen a Ralstonia (50\%). Se discute la posible participación de este género en la reproducción y desarrollo del caracol. Por otro lado, los filotipos bacterianos del intestino anterior y del intestino posterior incluyeron miembros de las clases Alphaproteobactera (12.5\%), Betaproteobacteria (12.5\%), Gammaproteobacteria (12.5\%), Bacilli (31.25\%), Clostridia (6.25\%), Actinobacteria (6.25\%), Mollicutes (6.25\%) y Deinococci (6.25\%). Conocer la composición bacteriana de la gónada y del intestino anterior y posterior de L. gigas es el primer paso para explorar el manejo adecuado de esta especie, y proporciona información útil para futuras investigaciones que permitan una mejor comprensión del papel de estas poblaciones bacterianas en la salud y la tasa reproductiva de $L$. gigas.

PALABRAS CLAVE: Lobatus gigas; Gen RNAr 16S; Comunidad Bacteriana; Gónada; Intestino.

\section{ABSTRACT}

$\mathrm{T}$ he microbial diversity of Lobatus gigas has not been thoroughly studied despite of them is a specie endangered. Knowledge of microbiota may help to improve the conservation and cultivation of this species. The objective of this study was to evaluate the bacterial populations associated with the gonad and the gut compartments of the wild endangered L. gigas from the Caribbean Seaflower Biosphere Reserve, using microbiological methods and culture-independent molecular tools. The genetic profiles of the bacterial populations were generated and Temporal Temperature Gradient Electrophoresis (TTGE) was used to compare them with total DNA. A genetic and statistical analysis of the bacterial communities revealed a low level of diversity in gonad tissue based on the number of bands detected using TTGE. In addition, statistical differences in bacterial community structure were found between the foregut and hindgut tissue of L. gigas. The dominant phylogenetic affiliations of the gonad bacteria, as determined using 16S rRNA gene sequencing, belong to Ralstonia (50\%). The possible involvement of this genus in the reproduction and development of the conch is discussed. On the other hand, the bacterial phylotypes from foregut and hindgut included members of Alphaproteobactera (12.5\%), Betaproteobacteria (12.5\%), Gammaproteobacteria (12.5\%), Bacilli (31.25\%), Clostridia (6.25\%), Actinobacteria (6.25\%), Mollicutes (6.25\%) and Deinococci (6.25\%) classes. Knowing the composition of the gonad and foregut and hindgut bacteria of $L$. gigas is the first step toward exploring the proper management of this species, as well as provides useful information to future researches that allow a better understanding of the role of these bacterial populations in the health and reproductive rate of L. gigas.

KEYWORDS: Lobatus gigas, 16S rRNA gene; Bacterial Community; Gonad; gut. 


\section{INTRODUCCIÓN}

El caracol rosado, Lobatus gigas, es una especie de importancia ecológica y económica en toda su área de distribución (Catarci, 2004). Esta especie juega un papel importante en las interacciones ecológicas de las poblaciones marinas cercanas a la costa, como uno de los principales herbívoros de algas marinas, algas epífitas y detritus. Además, es un organismo comensal, sirve como fuente de alimento para una amplia variedad de organismos marinos y compite con ellos por los recursos (Stoner and Waite, 1991; Tewfik, 1997; Catarci, 2004). Asimismo, es un recurso pesquero con valor económico en el comercio de alimentos marinos. Por lo tanto, muchos países deben establecer políticas para regular su explotación comercializándolo de manera sostenible sin poner en peligro su conservación. No obstante, a pesar del diseño y ejecución de medidas de gestión nacionales e internacionales para controlar la sobreexplotación y el acceso a este recurso, (Prada et al., 2008), su densidad poblacional continúa disminuyendo (Ballesteros et al., 2005; Stoner et al., 2012). Esta situación dificulta el mantenimiento adecuado de la población, lo que afecta a su capacidad de recuperación y hace que su comercialización sea insostenible (Stoner and Ray-Culp, 2000). En consecuencia, se ha incluido en el apéndice II de la Convención sobre el Comercio Internacional de Especies Amenazadas de Fauna y Flora Silvestres (CITES) (Daves and Fields, 2004). Se han establecido varias alternativas para superar esta situación y recuperar las poblaciones sobreexplotadas de L. gigas, como la creación de áreas marinas protegidas (AMP) (Appeldoorn, 1994; Stoner, 1996; Anon, 1999) que permitan preservar la alta densidad del stock de desove y el mantenimiento de un refugio para los adultos con mayor capacidad de reproducción (Anon, 1999). Otra alternativa es la acuicultura con técnicas dirigidas a la producción de juveniles (Brownell, 1977; Creswell, 1994).

En la Reserva de la Biosfera de Seaflower, se han establecido varias medidas de conservación para regular la pesca de L. gigas y mejorar la comprensión de su biología (Castro et al., 2007). Más específicamente, los estudios se han centrado principalmente en la genética poblacional (LandínezGarcía et al., 2011; Márquez et al., 2012), la dinámica y la biología reproductiva de este molusco (Aranda et al., 2001; Aranda et al., 2003a, b; Delgado et al., 2004; Castro et al., 2007). Sin embargo, estas alternativas de conservación no han tenido en cuenta los estudios sobre la microbiota, que es un aspecto fundamental del éxito del cultivo y la recuperación de organismos marinos. Por ejemplo, se ha demostrado en varias

\section{INTRODUCTION}

The Queen conch, Lobatus gigas, is a species of ecological and economic importance throughout its distribution area (Catarci, 2004). This species plays an important role in the ecological interactions of the near shore marine populations, as one of the main herbivores of seagrass, epiphyte algae and detritus. Additionally, it is a commensal organism, serves as a food source for a wide variety of marine organisms, and competes with them for resources (Stoner and Waite, 1991; Tewfik, 1997; Catarci, 2004). Furthermore, it is a fishery resource with economic value in the marine food trade. Thus, many countries are required to establish policies to regulate its exploitation by commercializing it in a sustainable way without jeopardizing its conservation. Nonetheless, despite the design and implementation of national and international management measures to control the overexploitation and access to this resource (Prada et al., 2008), their population density continues to decline (Ballesteros et al., 2005; Stoner et al., 2012). This condition hinders the proper maintenance of the population, affecting its self-healing abilities and rendering its commercialization unsustainable (Stoner and Ray-Culp, 2000). As a consequence, it has been included in appendix II of the Convention on International Trade in Endangered Species of Wild Fauna and Flora (CITES) (Daves and Fields, 2004). In order to overcome this situation and to recover the overexploited populations of L. gigas, several alternatives have been established, such as the creation of marine protected areas (MPA's) (Appeldoorn, 1994 ; Stoner, 1996; Anon, 1999) which allow the preservation of spawning stock at high densities and maintain a haven for adults with higher reproducibility (Anon, 1999). Another alternative is aquaculture with techniques directed to produce juveniles (Brownell, 1977; Creswell, 1994).

In the Seaflower Biosphere Reserve, several conservation measures have been stablished to regulate $L$. gigas fishing and to improve understanding of its biology (Castro et al., 2007). More specifically, studies have focused mainly on the population genetics (LandínezGarcía et al., 2011; Márquez et al., 2012), dynamics, and reproductive biology of this mollusk (Aranda et al., 2001; Aranda et al., 2003a, b; Delgado et al., 2004; Castro et al., 2007). But, these conservation alternatives did not consider studies on microbiota, which is a fundamental 
especies de peces y crustáceos que la comunidad microbiana influye en diversas funciones del hospedador, incluyendo el desarrollo, la digestión, la nutrición, y la resistencia e inmunidad a las enfermedades (Merrifield and Ringø, 2014), aspectos fundamentales para la salud de cualquier organismo. A pesar de esto, hasta la fecha se sabe muy poco acerca de cómo la microbiota influye en el crecimiento y desarrollo del caracol rosado (Kirjavainen and Gibson, 1999; Kowalik et al., 2006, Pérez et al., 2014). Recientemente, otros autores han analizado la microbiota del caracol rosado por medio de métodos dependientes de cultivo, identificación genotípica (Acosta et al., 2009, Pérez et al., 2014) y otros métodos independientes de cultivo (Pérez et al., 2014) utilizando muestras de intestino y de la secreción del caracol silvestre recolectadas cerca de la Isla del Rosario e Isla Tortugas en Colombia. Estos estudios demostraron la presencia de Pseudoalteromonas sp., Halomonas sp., Psychrobacter sp., Cobetia sp., Pseudomonas sp., Vibrio sp. y Burkholderia sp. (Acosta et al., 2009; Pérez et al., 2014). Cuartas et al., (2018), utilizando el análisis histológico, pirosecuenciación 454, y una combinación de amplificación por reacción en cadena de la polimerasa (PCR por sus siglas en inglés) y secuenciación Sanger indicaron que el agente etiológico de las protrusiones musculares es un parásito perteneciente a la subclase Digenea y está asociado a clados de bacterias y de hongos. Sin embargo, actualmente, no existen informes sobre la caracterización molecular de la microbiota bacteriana asociada a los compartimentos de la gónada y el tracto digestivo de L. gigas.

El tracto digestivo es un ecosistema mixto que contiene un consorcio de microorganismos dinámico y complejo, que desempeña un papel clave en la nutrición y salud del hospedador (Bäckhed et al., 2004). La microbiota intestinal está involucrada en procesos importantes, como la estimulación de la proliferación epitelial, el desarrollo del metabolismo de nutrientes y la respuesta inmune innata (Rawls et al., 2004; Sommer y Bäckhed, 2013; Thaiss et al., 2016). Por lo tanto, el conocimiento sobre las bacterias asociadas con los diferentes compartimentos del aparato digestivo podría ser útil para controlar la microbiota como estrategia para mejorar la nutrición, prevenir las infecciones por patógenos y desarrollar nuevas metodologías que contribuyan al éxito del cultivo de esta especie. Hasta la fecha, no hay estudios dirigidos a la identificación de las comunidades bacterianas que habitan la gónada del caracol y el papel potencial que desempeñan en la salud y el desarrollo de esta especie. No obstante, se ha reportado aspect of successful culture and restoration of marine organisms. For instance, it has been demonstrated in several species of fish and crustaceans that the microbial community influences various host functions including development, digestion, nutrition, disease resistance and immunity (Merrifield and Ringø, 2014), aspects that are fundamental to the health of any organism. Despite this, to date there is very little known about how the microbiota influence the growth and development of the queen conch (Kirjavainen and Gibson, 1999; Kowalik et al., 2006, Pérez et al., 2014). Recently, others have analyzed the queen conch microbiota through culture-dependent tools, genotypic identification (Acosta et al., 2009, Pérez et al., 2014) and culture-independent approaches (Pérez et al., 2014) using gut and secretion samples from wild conch collected near the Isla del Rosario and the Isla Tortugas in Colombia. These studies demonstrated the presence of Pseudoalteromonas sp., Halomonas sp., Psychrobacter sp., Cobetia sp., Pseudomonas sp., Vibrio sp. and Burkholderia sp. (Acosta et al., 2009; Pérez et al., 2014). Cuartas et al., (2018) using histological analysis, 454 pyrosequencing and a combination of PCR amplification and automated Sanger sequencing indicated that the etiological agent of the muscle protrusions is a parasite belonging to the subclass Digenea and is associated with bacterial and fungi clades. Nevertheless, currently, there are no reports about the molecular characterization of bacterial microbiota associated with the compartments of the gonad and the digestive tract of L. gigas.

The digestive tract is a compound ecosystem that contains a dynamic and complex consortium of microorganisms, which play a key role in the nutrition and health of the host (Bäckhed et al., 2004). The gut microbiota is involved in important processes, such as stimulation of epithelial proliferation, development of nutrient metabolism and innate immune response (Rawls et al., 2004; Sommer and Bäckhed, 2013; Thaiss et al., 2016). Thus, knowledge about the bacteria associated with the different gastrointestinal compartments could be useful to control microbiota as a strategy to improve nutrition, prevent pathogenic infections and to develop new methodologies that contribute to the successful culture of this species. To date, there are no studies aimed at identifying the bacterial communities that inhabit the conch gonad and the potential role on the health and the development of this species. Nonetheless, the presence of bacteria in the gonad has been reported in other mollusks, 
la presencia de bacterias en la gónada de otros moluscos, como Argopecten purpuratus donde se encontró la presencia permanente de los géneros Vibrio, Acinetobacter, Moraxella, Pseudomonas y Cytophaga en los órganos reproductivos (Chavez y Riquelme, 1994; Riquelme et al., 1995a). En el molusco Dendrodoris nigra, se determinó la presencia de bacterias en la gónada mediante microscopía electrónica, pero las mismas no fueron clasificadas (Klussmann-Kolb y Brodie, 1999). Aunque la microbiota gonadal es poco conocida en los organismos marinos, estudios previos del microbioma en mamíferos han demostrado que existe simbiosis entre bacterias y mamíferos. Estas bacterias desempeñan papeles importantes, como proporcionar protección contra la colonización de patógenos y producir compuestos antimicrobianos (Reid et al., 2011; Miller et al., 2017; Kindinger et al., 2017).

El objetivo principal del presente trabajo fue determinar la estructura de la comunidad bacteriana asociada a la gónada y a las diferentes secciones del intestino de $L$. gigas silvestres de la Reserva de la Biosfera de Seaflower del Caribe, utilizando un método dependiente de cultivo y otro independiente de cultivo. Además, analizamos la microbiota de muestras combinadas e individuales para estudiar la variación interindividual. Hasta donde sabemos, el presente trabajo es el primer examen de la microbiota bacteriana de la gónada y de todos los compartimentos intestinales del caracol rosado. Este enfoque permite la detección de las comunidades bacterianas dominantes que podrían tener relevancia en la reproducción y el desarrollo del caracol rosado.

\section{MATERIALES Y MÉTODOS}

\section{Recolección y procesamiento de muestras}

Veintidós muestras de L. gigas (caracol rosado), especímenes juveniles de aproximadamente $350 \mathrm{~g}$ cada uno, fueron recolectadas por pescadores en el Caribe colombiano, en el archipiélago de San Andrés $\left(12^{\circ}-16^{\circ} \mathrm{N}, 78^{\circ}-82^{\circ} \mathrm{O}\right)$. Las muestras fueron proporcionadas por la Gobernación del Archipiélago de San Andrés, Providencia y Santa Catalina, a través del convenio de cooperación científica \# 083/2012 (Cuartas et al., 2018). Los caracoles fueron transportados al laboratorio en hielo seco, donde se extrajo la gónada $(G)$, el intestino delgado (ID) e intestino grueso (IG) de cada caracol de forma aséptica en frío. Los tejidos extraídos de 15 caracoles con un peso similar se separaron en cinco grupos y cada grupo se homogeneizó y se denominó pool (P) de cada tejido. La combinación de muestras es una práctica común such as, Argopecten purpuratus where the permanent presence of the genera Vibrio, Acinetobacter, Moraxella, Pseudomonas and Cytophaga in the reproductive organs was found (Chavez and Riquelme, 1994; Riquelme et al., 1995a). In the mollusk Dendrodoris nigra the presence of bacteria in the gonad was determined by means of electron microscopy, but these bacteria were not classified (Klussmann-Kolb and Brodie, 1999). Although the gonad microbiota is poorly understood in marine organisms, previous studies using mammals suggests that the reproductive system microbiome is an important site of bacterial-mammalian symbiosis. These bacteria play important roles, such as, providing protection against pathobiont colonization and producing antimicrobial compounds (Reid et al., 2011; Miller et al., 2017; Kindinger et al., 2017).

The main objective of the present work was to estimate the bacterial community structure associated with gonad, and throughout the different sections of the gut of the wild L. gigas from the Caribbean Seaflower Biosphere Reserve, using culture-dependent and cultureindependent analysis. Also, we analyzed microbiota of pool and individuals to study inter-individual variation. To our knowledge, the present work is the first examination of bacterial microbiota of the gonad and throughout the gut compartments of queen conch. This approach enables the detection of dominant bacterial communities that could be of importance in the reproduction and development of the queen conch.

\section{MATERIALS AND METHODS}

\section{Sample Collection and Processing}

Twenty-two samples of $L$. gigas (queen conch) juvenile specimens of approximately $350 \mathrm{~g}$ each, were collected by fishermen in the Colombian Caribbean Sea, San Andres archipelago $\left(12^{\circ}-16^{\circ} \mathrm{N}\right.$ and between $78^{\circ}-$ $82^{\circ} \mathrm{O}$ ), these samples were provided by the Gobernación del Archipielago de San Andrés, Providencia y Santa Catalina, through the scientific cooperation agreement \#083/2012 (Cuartas et al., 2018). The conchs were transported to the laboratory on dry ice, where the gonad $(G)$, foregut $(F)$, and hindgut $(H)$ of each conch was aseptically extracted under cold conditions. Tissues removed from 15 conchs with similar weight were separated into five groups and each group was homogenized and referred to as a pool (P) of each tissue. Pooling 
para estudiar la microbiota intestinal en los peces (Hovda et al., 2007; Andlid et al., 1998; Romero and Navarrete, 2006). Los tejidos correspondientes a las siete (7) caracoles restantes se procesaron individualmente (I), para estudiar la variación interindividual (Romero y Navarrete, 2006). Finalmente, las muestras obtenidas de los tejidos ( $\mathrm{P}$ e I) se maceraron inmediatamente con nitrógeno líquido y luego se almacenaron a $-80^{\circ} \mathrm{C}$ hasta su procesamiento. Debido a que las comunidades bacterianas se obtuvieron de cada compartimento intestinal que contenía epitelio y alimentos digeridos, la microbiota analizada fue una combinación de bacterias autóctonas (capaces de colonizar la superficie epitelial o moco del intestino del hospedador) y alóctonas (transitorias o asociadas a la digestión) (Figura 1). samples is a common practice to study the gut microbiota in fish (Hovda et al., 2007; Andlid et al., 1998; Romero and Navarrete, 2006). The tissues corresponding to the seven (7) remaining conchs were processed individually (I), to study inter-individual variation (Romero and Navarrete, 2006). Finally, the samples obtained from tissues (P and I) were immediately macerated with liquid nitrogen and then stored at $-80^{\circ} \mathrm{C}$ until their processing. Since bacterial communities were obtained from each gut compartment that contained epithelium and digested food, the microbiota analyzed was a combination of both autochthonous (able to colonize the epithelial surface or mucus of the host gut) and allochthonous (transient or associated with digestion) bacteria (Figure 1).

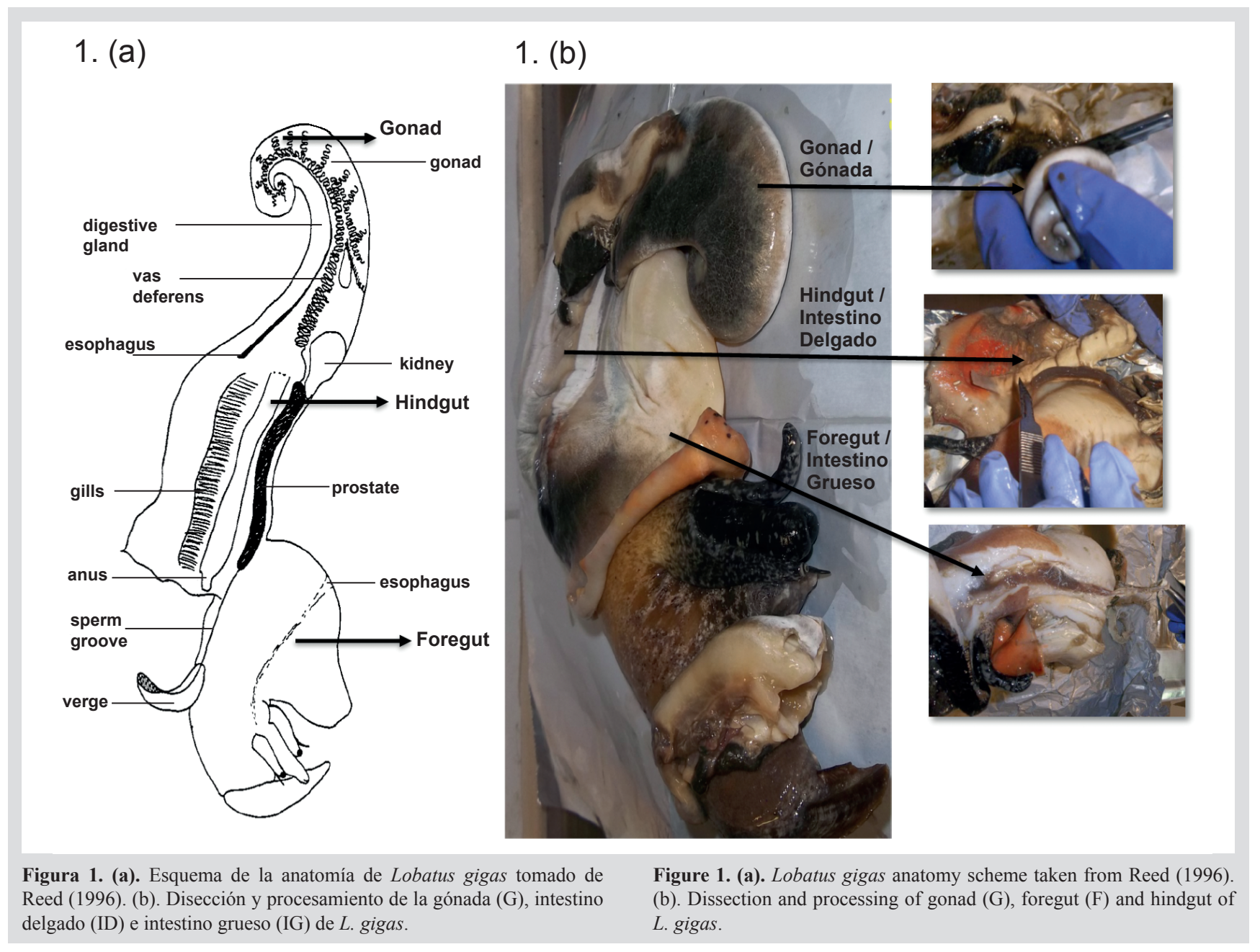

Para el método dependiente de cultivo, se sembraron diluciones en serie de homogeneizados de caracoles P o I en placas de agar marino (Difco) y agar tiosulfato-citrato-sales
For the culture-dependent analysis, serial dilutions of homogenates from either P or I conches were plated in marine agar (Difco) and Thiosulfate-citrate-bile salts- 
biliares-sacarosa (TCBS, Merck), y luego se incubaron las placas aeróbicamente a $20^{\circ} \mathrm{C}$ por 2 días. Las unidades formadoras de colonias (UFC) recuperadas de los diferentes medios se conservaron en un $20 \%$ de glicerol a $-80^{\circ} \mathrm{C}$ y se mencionaron como fracción cultivable (C). La fracción directa (D) se refiere a las muestras de tejido macerado congeladas $\mathrm{a}-80^{\circ} \mathrm{C}$ sin ser cultivadas (G, ID e IG). La nomenclatura de las muestras se resume en la Tabla 1. sucrose agar-TCBS (Merck), and then the plates were incubated aerobically at $20^{\circ} \mathrm{C}$ for 2 days. Colony forming units (CFUs) recovered from the different media were preserved in $20 \%$ glycerol at $-80^{\circ} \mathrm{C}$ and referenced as cultivable fraction (C). The direct fraction (D) refers to the macerated tissue samples frozen at $-80^{\circ} \mathrm{C}$ without being cultured (G, F, and H). Nomenclature of the samples is summarized in table 1 .
Tabla 1. Nomenclatura de las muestras obtenidas de los compartimentos del intestino y la gónada de Lobatus gigas de la Reserva de la Biosfera de Seaflower. $\mathrm{D}=\mathrm{ADN}$ total de la fracción directa, $\mathrm{C}=\mathrm{ADN}$ de la fracción cultivable, $\mathrm{I}=$ muestras individuales, $\mathrm{P}=$ pools, $\mathrm{G}=$ Gónada, $\mathrm{ID}=$ intestino delgado e $\mathrm{IG}=$ intestino grueso.
Table 1. Nomenclature of samples obtained from the gut compartments and gonad of Lobatus gigas from the biosphere reserve (SEAFLOWER). $\mathrm{D}=$ Total DNA from direct fraction, $\mathrm{C}=\mathrm{DNA}$ from cultivable fraction, $\mathrm{I}=$ individual samples, $\mathrm{P}=$ pools, $\mathrm{G}=\mathrm{Gonad}, \mathrm{F}=$ foregut and $\mathrm{H}=$ hindgut.

\begin{tabular}{|c|c|c|c|c|}
\hline $\begin{array}{l}\text { Nomenclatura } \\
\text { Nomenclature }\end{array}$ & $\begin{array}{l}\text { Extracción de ADN } \\
\text { DNA Extraction }\end{array}$ & $\begin{array}{l}\text { Orígenes } \\
\text { Origen }\end{array}$ & $\begin{array}{l}\text { Proceso } \\
\text { Process }\end{array}$ & $\begin{array}{l}\text { Muestras } \\
\text { Samples }\end{array}$ \\
\hline CIDI / CFI & $\begin{array}{l}\text { Fracción cultivable "C" / } \\
\text { Cultivable fraction "C" }\end{array}$ & $\begin{array}{l}\text { Intestino delgado "ID" } \\
\text { Foregut "F" }\end{array}$ & Individual "I" & $\begin{array}{l}\text { CIDI2, CIDI3, CIDI4, CIDI6, CIDI16 } \\
\text { CFI2, CFI3, CFI4, CFI6, CFI16 }\end{array}$ \\
\hline $\mathrm{CIDP} / \mathrm{CFP}$ & & & Pool "P" & $\begin{array}{l}\text { CIDP1, CIDP2, CIDP4, CIDP5 } \\
\text { CFP1, CFP2, CFP4, CFP5 }\end{array}$ \\
\hline CIGI / CHI & & $\begin{array}{l}\text { Intestino grueso "IG" } \\
\text { Hindgut "H" }\end{array}$ & Individual "I" & $\begin{array}{l}\text { CIGI2, CIGI3, CIGI6, CIGI16 } \\
\text { CHI2, CHI3, CHI6, CHI16 }\end{array}$ \\
\hline $\mathrm{CIGP} / \mathrm{CHP}$ & & & Pool "P" & $\begin{array}{l}\text { CIGP1, CIGP2, CIGP4, CIGP5 } \\
\text { CHP1, CHP2, CHP4, CHP5 }\end{array}$ \\
\hline CGI / CGI & & $\begin{array}{l}\text { Gónada "G" } \\
\text { Gonad "G" }\end{array}$ & Individual "I" & CGI3, CGI4, CGI6, CGI16 \\
\hline CGP / CGP & & & Pool "P" & CGP1, CGP2, CGP4, CGP5 \\
\hline DIDI / DFI & $\begin{array}{l}\text { Fracción directa "D" / } \\
\text { Direct fraction "D" }\end{array}$ & $\begin{array}{l}\text { Intestino delgado "ID" } \\
\text { Foregut "F" }\end{array}$ & Individual "I" & $\begin{array}{l}\text { DIDI2, DIDI3, DIDI6, DIDI16 } \\
\text { DFI2, DFI3, DFI6, DFI16 }\end{array}$ \\
\hline DIDP / DFP & & & Pool "P" & $\begin{array}{l}\text { DIDP1, DIDP2, DIDP3, DIDP4, DIDP5 } \\
\text { DFP1, DFP2, DFP3, DFP4, DFP5 }\end{array}$ \\
\hline DIGI / DHI & & $\begin{array}{l}\text { Intestino grueso "IG" } \\
\text { Hindgut "H" }\end{array}$ & Individual "I" & $\begin{array}{l}\text { DIGI2, DIGI3, DIGI6, DIGI16 } \\
\text { DHI2, DHI3, DHI6, DHI16 }\end{array}$ \\
\hline DIGP / DHP & & & Pool "P" & $\begin{array}{l}\text { DIGP1, DIGP2, DIGP3, DIGP4, DIGP5 } \\
\text { DHP1, DHP2, DHP3, DHP4, DHP5 }\end{array}$ \\
\hline DGI / DGI & & $\begin{array}{l}\text { Gónada "G" } \\
\text { Gonad "G" }\end{array}$ & Individual "I" & DGI3, DGI4, DGI6, DGI16 \\
\hline DGP / DGP & & & Pool "P" & DGP1, DGP2, DGP3, DGP4, DGP5 \\
\hline
\end{tabular}

\section{Extracción de ADN}

El ADN de la fracción cultivable (C) de cada muestra se extrajo con un kit de purificación de ADN a partir de sangre y tejido DNEasy (Qiagen, Düsseldorf, Alemania) utilizando un protocolo de extracción de ADN de DNEasy modificado para asegurar la lisis de las bacterias Gram positivas y Gram negativas, según lo descrito por Li et al. (2009).

La extracción del ADN genómico total de la fracción directa(D) de cada tejido se realizó utilizando un kit de extracción de ADN en suelo Ultraclean previa lisis tisular, como describen Ó Cuív et al. (2011). Brevemente, cada tejido diseccionado de $L$. gigas se obtuvo como se ha descrito anteriormente, se homogeneizaron $300 \mathrm{mg}$ con $800 \mu \mathrm{l}$ de tampón de lisis $(6 \mathrm{mM}$ Tris- $\mathrm{HCl}$ [pH 8], $100 \mathrm{mM}$ EDTA, $1 \mathrm{M} \mathrm{NaCl})$ y se incubaron

\section{DNA Extraction}

The DNA from the cultivable fraction (F) of each sample was extracted with a DNEasy tissue kit (Qiagen, Duesseldford, Germany) using a modified DNEasy DNA extraction protocol to ensure lysis of Gram positive and Gram negative bacteria, as described by Li et al. (2009).

The total genomic DNA from the direct fraction (D) of each tissue was extracted using an Ultraclean soil DNA extraction kit with a prior tissue lysis step, as described by Ó Cuív et al. (2011). Briefly, each dissected tissue from L. gigas was obtained as described above and $300 \mathrm{mg}$ were homogenized with $800 \mu \mathrm{l}$ of lysis buffer (6 $\mathrm{mM}$ Tris- $\mathrm{HCl}$ [pH 8], $100 \mathrm{mM}$ EDTA, $1 \mathrm{M} \mathrm{NaCl}$ ) and 
a $75^{\circ} \mathrm{C}$ durante 10 minutos para inactivar las nucleasas. Se añadieron $20 \mu \mathrm{l}$ de lisozima $(200 \mathrm{mg} / \mathrm{ml})$ y se incubaron las muestras durante toda la noche a $37^{\circ} \mathrm{C}$. Posteriormente, se realizó una digestión con $20 \mu \mathrm{l}$ de proteinasa $\mathrm{K}(20 \mathrm{mg} / \mathrm{ml})$ a $56^{\circ} \mathrm{C}$ hasta la lisis completa de cada tejido.

\section{Amplificación por PCR}

Para obtener la huella molecular de la comunidad bacteriana del intestino delgado, el intestino grueso y la gónada mediante cultivo en agar marino (C), el gen RNAr 16S entre la región V3 y V6 se amplificó con iniciadores específicos $341 \mathrm{~F}$ con una terminación extra de GC (5' GCCTACGGGAGGCAGCAG 3'), y 907R (5' CCGTCAATTCMTTTGAGTTT 3') (McCracken et al., 2001). La PCR se llevó a cabo siguiendo las condiciones descritas por García et al. (2016).

La amplificación de la región hipervariable entre las regiones V3 y V6 del gen RNAr 16S de la fracción D se realizó con una PCR anidada. La primera PCR se llevó a cabo para amplificar la secuencias del gen RNAr 16S de longitud casi completa con iniciadores universales $27 \mathrm{~F}$ (5`AGAGTTTGATCMTGGCTCAG 3') y 1492R (5' GTTACCTTGTTACGACTT 3') siguiendo las condiciones descritas por Espejo and Romero (1997). Luego, se usaron 2,5 $\mu l$ del producto de la primera PCR como molde de ADN en la segunda reacción, que se realizó con los iniciadores específicos $341 \mathrm{~F}(\mathrm{GC})$ y $907 \mathrm{R}$ (como se ha descrito previamente para las muestras cultivables) y siguiendo las condiciones reportadas por Espejo et al. (1998).

Análisis de electroforesis en gel de gradiente temporal de temperatura (TTGE, por sus siglas en inglés)

Se determinó la estructura de las comunidades bacterianas asociadas con el intestino delgado, el intestino grueso y la gónada mediante la técnica TTGE, que permitió separar fragmentos del gen RNAr 16S de aproximadamente 585 pb, con la suposición de que cada banda observada en los perfiles representa una especie bacteriana.

Los productos de la PCR obtenidos de ambas fracciones, usando los iniciadores $341 \mathrm{~F}(\mathrm{GC})$ y $907 \mathrm{R}$, se separaron mediante TTGE usando el Sistema Universal de Detección de Mutaciones DCode (BioRad, EE. UU.) en poliacrilamida al $7 \%(\mathrm{p} / \mathrm{v})$, geles de urea $7 \mathrm{M}$ en tampón TAE $1,25 \mathrm{X}$ durante 15 horas a $55 \mathrm{~V}$. La temperatura inicial y final fue de $66{ }^{\circ} \mathrm{C}$ y $69{ }^{\circ} \mathrm{C}$, respectivamente, con un incremento de temperatura de $0,1^{\circ} \mathrm{C}$ por hora. Los geles se tiñeron con $\mathrm{AgNO}_{3}$ (AMRESCO, OH, USA) (Sanguinetti et al., 1994). Los perfiles obtenidos para cada muestra estudiada se analizaron incubated at $75^{\circ} \mathrm{C}$ for 10 minutes to inactivate nucleases. $20 \mu \mathrm{l}$ of lysozyme were added $(200 \mathrm{mg} / \mathrm{ml})$ and incubated overnight at $37^{\circ} \mathrm{C}$. Subsequently, a digestion with $20 \mu \mathrm{l}$ of proteinase $\mathrm{K}(20 \mathrm{mg} / \mathrm{ml})$ at $56^{\circ} \mathrm{C}$ was performed until complete lysis of each tissue.

\section{PCR amplification}

In order to obtain molecular fingerprinting of the bacterial community from the foregut, hindgut and gonad cultured on marine agar (C), the 16S rRNA gene between V3 and V6 region was amplified with specific primers $341 \mathrm{~F}$ with an extra GC tail (5 'GCCTACGGGAGGCAGCAG 3') and 907R (5'CCGTCAATTCMTTTGAGTTT 3') (McCracken et al., 2001). The PCR was carried out using the conditions described by García et al. (2016).

Amplification of the hypervariable region between V3 and V6 regions of 16S rRNA from the D was performed with a nested PCR. The first PCR was carried out to amplify nearly full-length $16 \mathrm{~S}$ rRNA gene sequences with universal primers $27 \mathrm{~F}$ (5`AGAGTTTGATCMTGGCTCAG $3^{\prime}$ ) and 1492R (5' GTtACCTTGTTACGACTT 3') following the conditions given by Espejo and Romero (1997). Then, $2.5 \mu \mathrm{l}$ from the product of the first PCR were used as template DNA in the second reaction, which was performed with the specific primers $341-\mathrm{GC} F$ and $907 \mathrm{R}$ (as described previously for cultivable samples) and under the conditions reported by Espejo et al. (1998).

\section{Temporal Temperature Gradient Electrophoresis} (TTGE) analysis

The structure of bacterial communities associated with the foregut, hindgut and gonad was revealed using the TTGE technique, which allowed separating fragments of the 16S rRNA gene of approximately 585 $\mathrm{bp}$, with the assumption that each band observed in the banding patterns represents a bacterial species.

The PCR products obtained from both fractions, using the $341 \mathrm{~F}-\mathrm{GC}$ and $907 \mathrm{R}$ primers, were separated by TTGE using the DCode Universal Mutation Detection System (BioRad, USA) on 7\% (w/v) polyacrylamide, $7 \mathrm{M}$ Urea gels in $1.25 \mathrm{X}$ TAE buffer for $15 \mathrm{~h}$ at $55 \mathrm{~V}$. The initial and final temperatures were $66^{\circ} \mathrm{C}$ and $69^{\circ}$ respectively, with a temperature ramp of $0.1^{\circ} \mathrm{C}$ per hour. The gels were stained with $\mathrm{AgNO}_{3}$ (AMRESCO, OH, USA) (Sanguinetti et al., 1994). The band patterns obtained for each sample studied were analyzed using 
usando el programa GelCompar II (Applied Maths TX, USA) (Rademaker y De Bruijn, 2008, Garcia et al., 2016). Los carriles de referencia de cada muestra se alinearon en base a una escala de $100 \mathrm{pb}$, y se realizó un análisis de agrupamientousando el coeficiente DICE (Nei and Li, 1979) y el método de agrupación de pares no ponderados con medias aritméticas (UPGMA, por sus siglas en inglés) (Mohammadi y Prasanna, 2003).

\section{Análisis de la comunidad bacteriana}

Se utilizó el programa GelCompar II (Applied Biosystems, Bélgica) para analizar los perfiles de TTGE a partir de las muestras de ADN. Para este análisis, se utilizó la matriz de presencia y ausencia para generar un análisis de similitud (ANOSIM, por sus siglas en inglés) basado en el índice de Bray-Curtis, utilizando el programa PAST versión 2.0 (Hammer et al., 2001). Se evaluaron las diferencias significativas de la diversidad bacteriana con la opción "Diversity t-test" del programa PAST. Para este análisis, se consideró que el número de banda representaba el número de especie o Taxón (S) y la intensidad de la banda la abundancia relativa o el número de individuos de cada especie bacteriana. La opción "Análisis de componentes principales" se usó para ver las similitudes y diferencias generales entre el muestreo de la gónada, el intestino delgado e intestino grueso, y entre la fracción cultivable (C) y la directa (D) de cada tejido (Chaiyapechara et al., 2012; Pérez et al., 2014, Boon, 2002). Esta distribución de agrupamiento fue verificada por el análisis llevado a cabo con las dos réplicas de gel. Finalmente, el índice de Shannon (H') que refleja la diversidad de la comunidad bacteriana de ID, IG y G se calculó siguiendo la fórmula: $\mathrm{H}^{`}=-\mathrm{SP}_{\mathrm{i}} \ln \mathrm{P}_{\mathrm{i}}$, donde $P_{i}$ se define como $\left(n_{i} N\right), n_{i}$ es cada banda presente, $y$ $\mathrm{N}$ es la suma de todas las bandas (Sun et al., 2011).

Las bandas TTGE con patrones de migración únicos según la escalera de DNA GenRuler ${ }^{\mathrm{TM}} 100 \mathrm{bp}$ (Thermo Fisher Scientific) y las bandas de mayor intensidad en cada TTGE, se escindieron, y el ADN se eluyó siguiendo el método de molienda húmeda descrito por Sambrook y Russell (2002). Luego se tomaron $5 \mu$ de la elución final y se volvieron a amplificar con los iniciadores $341 \mathrm{~F}$ sin terminación de GC y 907R. Los productos reamplificados de la fracción $\mathrm{C}$ se verificaron mediante electroforesis en gel de agarosa al $1 \%$. Los productos amplificados de la fracción D se purificaron utilizando el kit de purificación de productos de PCR QIAquick (QIAGEN CA, EE. UU.) y se clonaron en células competentes de E. coli DH5 $\alpha$ usando un kit de clonación Clone JET ${ }^{\mathrm{TM}}$ (Thermo Scientific, EE.
GelCompar II (Applied Maths TX, USA) (Rademaker and De Bruijn, 2008, Garcia et al., 2016). The reference lanes from each sample were aligned according to a 100 bp ladder, and a cluster analysis was performed using DICE coefficient (Nei and Li, 1979) and the Unweighted Pair Group Method with Arithmetic Average (UPGMA) (Mohammadi and Prasanna, 2003).

Bacterial community analysis

GelCompar II software (Applied Biosystems, Belgium) was used to analyze TTGE profile patterns from the DNA samples. For this analysis, the presence and absence matrix was used to generate an analysis of similarity (ANOSIM) based on the Bray-Curtis index using PAST software version 2.0 (Hammer et al., 2001). Significant differences in bacterial diversity were assessed with the "Diversity t-test" option of the PAST program. For this analysis, the band number was considered to represent the species number or Taxa (S) and the band intensity was considered to represent the relative abundance or number of individuals of each bacterial species. The "Principal Component Analysis" option was used to view overall similarities and dissimilarities among sampling of the gonad, foregut and hindgut and between the cultivable (C) and direct (D) fraction from each tissue (Chaiyapechara et al., 2012; Pérez et al., 2014, Boon, 2002). This clustering distribution was confirmed by the analysis carried out with the two gel replicates. Finally, the Shannon index $\left(\mathrm{H}^{\prime}\right)$ which reflects the diversity of the bacterial community of F, H and $\mathrm{G}$ was calculated following the formula: $\mathrm{H}^{`}=-\mathrm{SP}_{\mathrm{i}} \ln \mathrm{P}_{\mathrm{i}}$, where $\mathrm{P}_{\mathrm{i}}$ is defined as $\left(\mathrm{n}_{\mathrm{i}} / \mathrm{N}\right), \mathrm{n}_{\mathrm{i}}$ is each band present, and $\mathrm{N}$ is the sum of all bands (Sun et al., 2011).

TTGE bands with unique migration patterns according to the GenRuler ${ }^{\mathrm{TM}} 100 \mathrm{bp}$ DNA ladder (Thermo Fisher Scientific) and bands with higher intensity in each TTGE, were cleaved and DNA was eluted following the Soak and Crush method described by Sambrook and Russell (2002). Then $5 \mu$ from the final elution were taken and re-amplified with primers $341 \mathrm{~F}$ without GC tail and 907R. Re-amplified products from the $\mathrm{C}$ fraction was verified by gel electrophoresis on a $1 \%$ agarose gel. The re-amplified products from D were purified using the QIAquick PCR purification kit (QIAGEN CA, U.S.A) and cloned into E. coli DH5 $\alpha$ competent cells 
UU.). La ligadura se realizó siguiendo las indicaciones del fabricante y se completó la transformación según lo descrito por Sambrook y Russell (2002). El inserto se amplificó siguiendo las recomendaciones del kit de purificación QIAquick (QIAGEN CA, EE. UU.) con los iniciadores pJET1.1 y pJET1.2. Los amplicones de D y C se secuenciaron en un Analizador Genético ABI Prism 3100 (Applied Biosystems, CA, EE. UU.).

Las secuencias de DNAr 16S obtenidas de ambas fracciones se editaron usando BioEdit ${ }^{\circledR}$ (Hall, 1999) y se determinó la presencia de quimeras con el programa en línea DECIPHER v2.0 descrito por Wright et al. (2012). Las secuencias editadas se compararon luego con las secuencias de referencia del Centro Nacional de Información Biotecnológica (NCBI, por sus siglas en inglés) y del Proyecto de Base de Datos Ribosomal (RDP, por sus siglas en inglés). Para determinar la afiliación filogenética de los aislamientos microbianos y las bandas obtenidas, se realizaron búsquedas de similitud y análisis filogenéticos utilizando los programas BLASTN y MEGA 7 (Tamura et al., 2007). El análisis filogenético se realizó utilizando el método del vecino más cercano (Saitou y Nei, 1987) con 1000 replicaciones bootstrap. Se enraizó con una secuencia del gen RNAr 16S de Crenarchaeote simbionte de Axinella sp., con el fin de mejorar la topología. Las secuencias obtenidas en este estudio se depositaron en el GenBank con los números de acceso KX891431-KX891450 y KX886796 -KAX886797.

\section{RESULTADOS}

\section{Recuento bacteriano}

La Tabla 2 presenta la abundancia bacteriana promedio de la fracción cultivable en los compartimentos del tracto digestivo y de la gónada en cada medio, expresándose como UFC por gramo de tejido. Los promedios de la abundancia de bacterias que se obtuvieron de la gónada cultivada tanto en agar marino como en TCBS fueron $1,21 \times 10^{7}$ y $2,83 \times 10^{7}$ UFC por gramo de tejido, respectivamente. Los recuentos en agar TCBS indicaron una abundancia similar en ambos compartimentos digestivos $\left(1,01 \times 10^{7}\right.$ UFC por gramo de tejido), mientras que, por el contrario, los recuentos de las bacterias del intestino delgado cultivadas en agar marino revelaron una concentración de bacterias heterotróficas cinco veces superior a la del intestino grueso. using a Clone JET TM kit (Thermo Scientific, U.S.A). Ligation was performed following the manufacturer's indications and transformation was completed as described by Sambrook and Russell (2002). The insert was amplified following the QIAquick purification kit (QIAGEN CA, U.S.A) recommendations with pJET1.1 and pJET 1.2 primers. Amplicons from D and $\mathrm{C}$ were sequenced in on an ABI PrimR 3100 Genetic Analyser (Applied Biosystems, CA, USA).

Sequences of $16 \mathrm{~S}$ rDNA obtained from both fractions were edited using BioEdit ${ }^{\circledR}$ (Hall, 1999) and the presence of chimeras was assessed with the online software DECIPHER v2.0 described by Wright et al. (2012). The edited sequences were then compared with reference sequences from The National Center for Biotechnology information (NCBI) and Ribosomal Database Project (RDP). To determine the phylogenetic affiliation of the microbial isolates and the excised bands, similarity searches and phylogenetic analysis were performed using the BLASTN and MEGA 7 software (Tamura et al., 2007). Phylogenetic analysis was performed using the Neighbor-Joining method (Saitou and Nei, 1987) with 1000 bootstrap replicates. It was rooted with a $16 \mathrm{~S}$ rRNA gene sequence from Crenarchaeote symbiont of Axinella sp., in order to improve the topology. The sequences obtained in this study were deposited in GenBank under accession numbers KX891431-KX891450 and KX886796 -KAX886797.

\section{RESULTS}

\section{Bacterial count}

The average cultivable bacterial abundance of gut tract compartments and gonad in each medium is observed in Table 2 and expressed as CFUs per gram of tissue. The averages of bacterial abundance recovered from the gonad and cultured in marine and TCBS agar were $1,21 \times 10^{7}$ y $2,83 \times 10^{7}$ CFUs per gram of tissue, respectively. The TCBS agar counts indicated a similar abundance in both gut compartments $\left(1.01 \times 10^{7} \mathrm{CFUs}\right.$ per gram of tissue), while on the other hand, the counts from the foregut bacteria cultured in marine agar revealed a concentration of heterotrophic bacteria five times greater than the hindgut. 
Tabla 2. Abundancia bacteriana promedio (UFC/g) de la gónada, el intestino delgado e intestino grueso en cultivos de agar marino y TCBS.
Table 2. Average bacterial abundance (CFUs/g) from gonad, foregut and hindgut cultured in marine and TCBS agar.

\begin{tabular}{|l|c|c|}
\hline \multicolumn{1}{|c|}{$\begin{array}{l}\text { Tejido } \\
\text { Tissue }\end{array}$} & $\begin{array}{c}\text { Agar marino (UFC/g) } \\
\text { Marine Agar (CFU/g) }\end{array}$ & $\begin{array}{c}\text { Agar TCBS (UFC/g) } \\
\text { Agar TCBS (CFU/g)T }\end{array}$ \\
\hline $\begin{array}{l}\text { Intestino delgado } \\
\text { Foregut }\end{array}$ & $5.57 * 107$ & $1.01 * 107$ \\
$\begin{array}{l}\text { Intestino grueso } \\
\text { Hindgut } \\
\begin{array}{l}\text { Gónada } \\
\text { Gonad }\end{array}\end{array}$ & $1.10 * 107$ & $1.00 * 107$ \\
\hline
\end{tabular}

\section{Análisis de los perfiles de PCR-TTGE}

La estructura de la comunidad bacteriana asociada con los tejidos de la gónada e intestinales obtenida en la fracción cultivable "C" y la fracción directa "D" se evaluó por medio del perfil TTGE de los fragmentos del gen RNAr 16S (Figura 2A y Figura 2B). Los resultados de los perfiles de bandas, evaluados con el programa GelCompar II, revelaron la presencia de varios patrones de migración; estos perfiles revelaron diferencias entre las comunidades bacterianas asociadas a cada tejido y las muestras de la fracción "D" presentaron patrones más complejos y bandas más diversas en comparación con la fracción cultivable "C".

A partir de este análisis en gel (Figura 2), se seleccionaron 105 bandas de ADN (69 de intestino y 36 de la gónada) únicas y comunes en función de la intensidad de la banda. Con respecto a la gónada de Lobatus gigas, la banda G38 mostró una población predominante asociada con las muestras individuales y combinadas de la fracción directa. La fracción cultivable se caracterizó por la presencia de las bandas G1 y G8 en tres muestras combinadas y cuatro muestras individuales (Figura 2A). Los resultados de las secuencias de bandas de ADN se presentan en la Tabla 4.

Los perfiles genéticos y el análisis de agrupamiento realizados a partir de la fracción directa y cultivable de la gónada revelaron dos grupos diferentes según la fracción, con una similitud del 22,2\% para el grupo A y del 27,9\% para el grupo B (Figura 3A). Se formaron dos subgrupos en el grupo A a partir de las muestras de la fracción cultivable, una de ellas con una similitud superior al $60 \%$ y la otra con un nivel de similitud del 50\%. El grupo B contenía las muestras de las fracciones directas (Figura 3A).

Por otro lado, los perfiles genéticos obtenidos con el método UPGMA para el análisis de agrupamiento del intestino delgado e intestino grueso mostraron seis grupos A, B, C, D, E y F con porcentajes de similitud de $20.7,45,38.9,33.1$ y $44.6 \%$, respectivamente (Figura
Analysis of PCR-TTGE profiles

The estimation of the bacterial community that were associated with gonad and gut tissues and between cultivable "C" and direct " $\mathrm{D}$ " fraction were evaluated through TTGE profiling of partial 16S rRNA genes (Figure $2 \mathrm{~A}$ and Figure 2B). The results of the banding profiles, evaluated using the program GelCompar II, revealed the presence of several migration patterns, these profiles revealed differences between the bacterial communities associated with each tissue and the " $D$ " fraction samples exhibited more complex patterns and more diverse bands compared with those of the cultivable "C" fraction.

From this gel analysis (Figure 2), 105 (69 of gut and 36 gonad) unique and common DNA bands were selected based on the band intensity. Referring to the gonad of Lobatus gigas, the G38 band showed a predominant population associated with individual and pooled samples from the direct fraction. The cultivable fraction was characterized by the presence of bands G1 and G8 in three pools and four individual samples (Figure 2A). The results of the DNA bands sequences are provided in Table 4.

The genetic profiles and the clustering analysis performed from direct and cultivable fraction of the gonad revealed two different groups according to the fraction, with $22.2 \%$ similarity for group A and $27.9 \%$ for group B (Figure 3A). Two subgroups were formed in group A from cultivable fraction samples, one of them with a higher than $60 \%$ similarity and the other with a similarity level of $50 \%$. Group B contained the samples from the direct fractions (Figure 3A).

On the other hand, the genetic profiles with the UPGMA method for the clusters analysis of foregut and hindgut showed six groups A, B, C, D, E and F with similarity percentages of 20.7, 45, 38.9, 33.1 and 
A

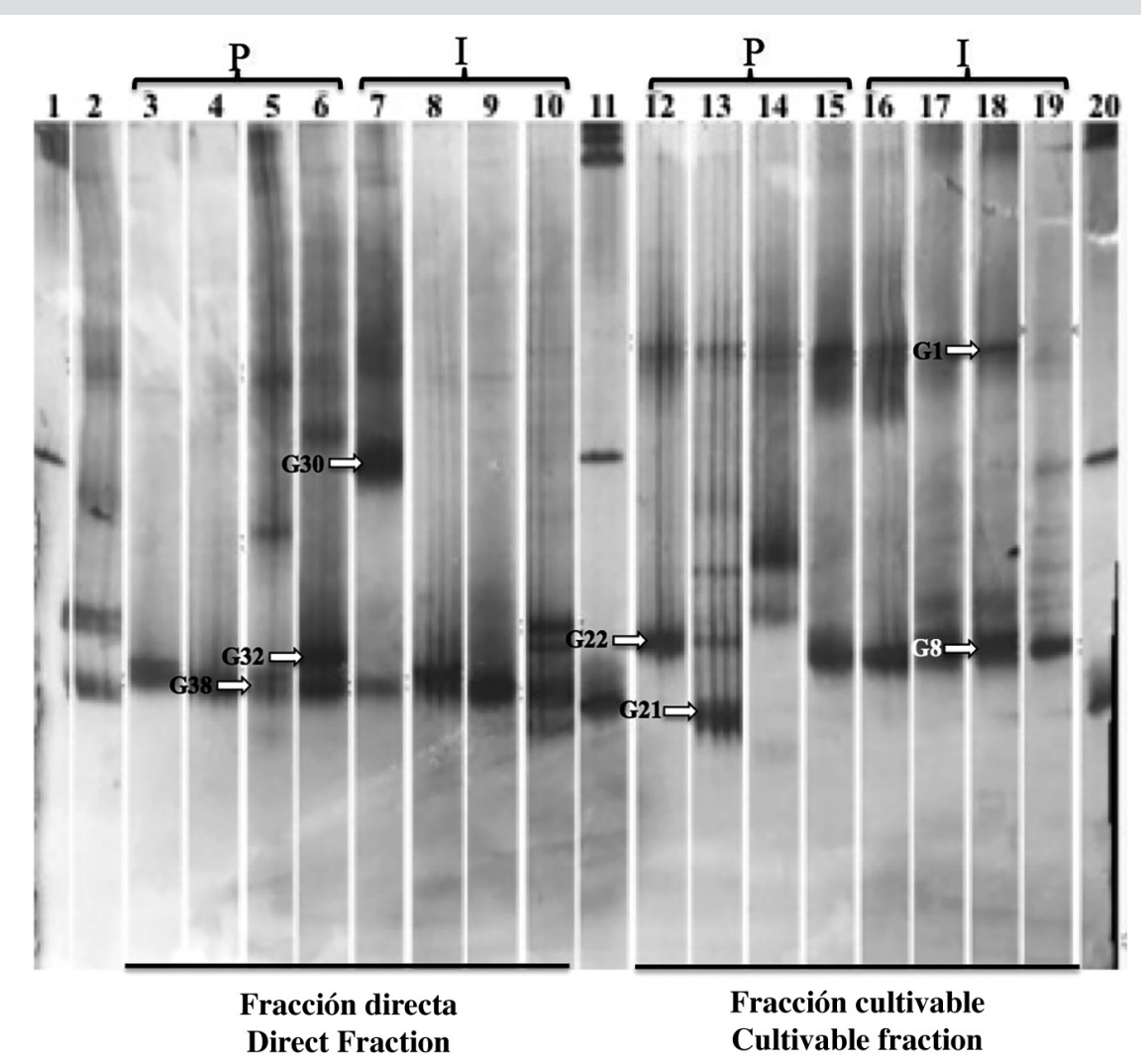

B

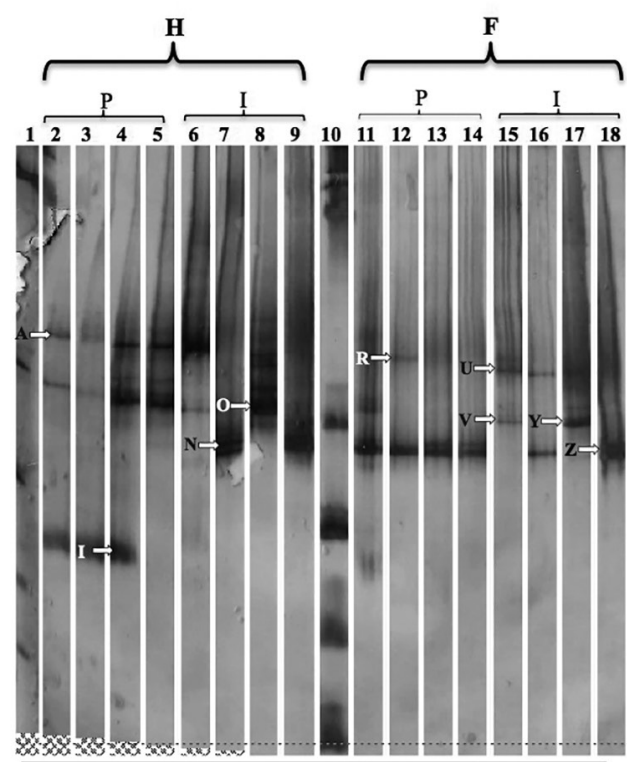

Fracción cultivable (C) Cultivable fraction $(C)$

Figura 2. Perfil TTGE de la región V3-V6 del gen RNAr 16S de las fracciones cultivable y directa de la gónada (A), y del intestino delgado e intestino grueso (B). Los rótulos encima de la imagen indican el origen de las muestras. "G" para la gónada, "ID" para el intestino delgado e "IG" para el intestino grueso, "P" para el pool e "I" para el individuo. Los carriles marcados con "L" corresponden a marcadores de 100 pb utilizados como referencia. Los códigos sobre cada carril indican las bandas seleccionadas para la secuenciación.
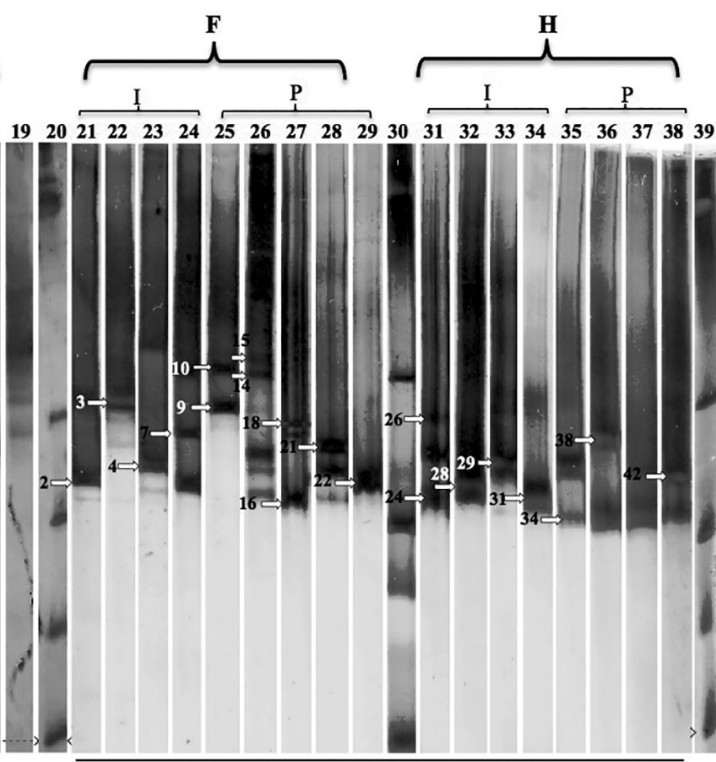

Fracción directa (D)

Direct Fraction (D)

Figure 2. TTGE profile of V3-V6 region of $16 \mathrm{~S}$ rRNA gene from cultivable and direct fraction gonad (A) and foregut, hindgut (B). The labels above the image indicate the samples origin. "G" for gonad, "F" for foregut and "H" for hindgut, "P" for pool and "I" for individual. The lanes labeled with "L" correspond to markers of $100 \mathrm{bp}$ used as references. The codes above each lane indicate the bands selected for sequencing. 
A

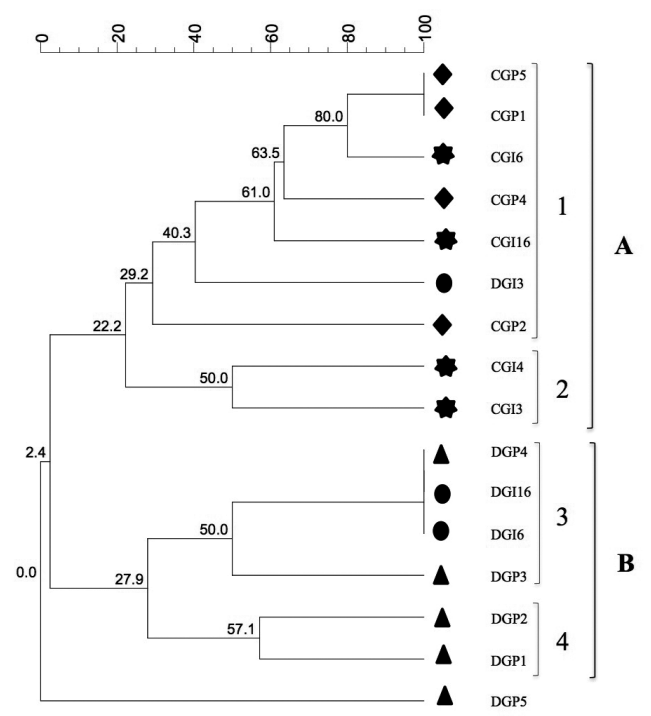

B

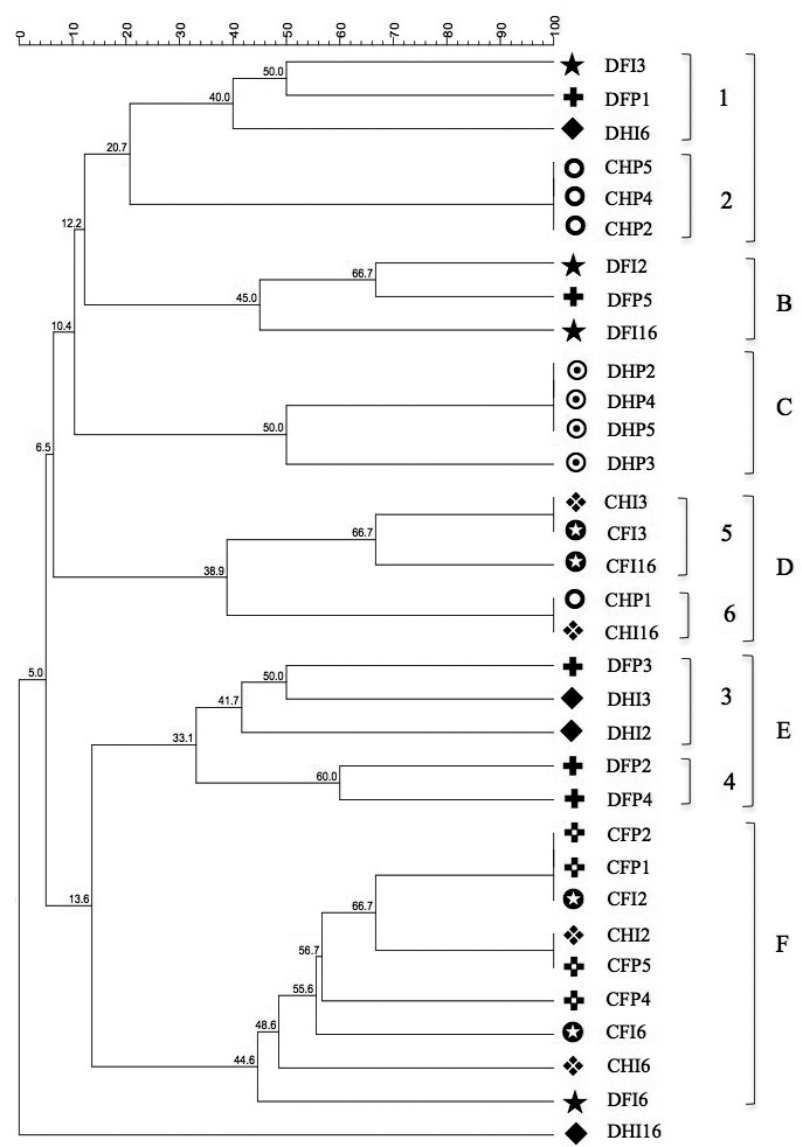

Figura 3. Análisis de agrupamiento de los perfiles de TTGE de la fracción cultivable "C" y fracción directa "D" de las muestras individuales "I" y combinadas "P" de la gónada "G" (A), y del Intestino delgado "ID" e Intestino grueso "IG" (B) de L. gigas. El análisis de agrupamiento se realizó con el programa Gel compare II ${ }^{\circledR}$ utilizando el coeficiente de Dice y el método de agrupación de pares no ponderados con medias aritméticas (UPGMA) (Mohammadi and Prasanna, 2003). Las letras de la A a la F y los números representan los grupos y subgrupos generados, respectivamente.
Figure 3. TTGE banding patterns cluster analysis from cultivable "C" and direct "D" fraction of individual "I" and pools "P" samples of gonad "G" (A) and foregut "F" and hindgut " $\mathrm{H}$ " (B) of L. gigas. The cluster analysis was performed with Gel compare II ${ }^{\circledR}$ software using Dice coefficient and Unweighted - Pair Group Method with Arithmetic Mean (UPGMA) (Mohammadi and Prasanna, 2003). The letters from A to F and the numbers represent the groups and the sub-groups generated, respectively. 
3B). El grupo A está compuesto por muestras del intestino delgado e intestino grueso, tanto de la fracción cultivable como directa; sin embargo, también se formaron dos subgrupos de acuerdo a la fracción de la que procedían las muestras (Figura 3B, subgrupo 1 y 2). El grupo B agrupó dos muestras individuales (DIDI2 y DIDI16) y una combinada (DIDP5) de la fracción directa del intestino delgado, con un porcentaje de similitud del $45 \%$. El grupo C contenía todas las muestras de la fracción directa del intestino grueso, con un porcentaje de similitud superior al 50\%. En el grupo D, se combinaron las muestras de la fracción cultivable, con porcentajes de similitud de 38.9\% y $44.6 \%$ respectivamente, y se observó un alto porcentaje de similitud en la población bacteriana del intestino delgado. Además, las muestras de las fracciones directas se combinaron principalmente en los grupos B, C y E, con una similitud de 45,50 y $33.1 \%$, respectivamente. El grupo E contenía muestras del intestino delgado e intestino grueso de las fracciones directas, con niveles de similitud superiores al $33.1 \%$.

Las variaciones en las comunidades bacterianas presentes en los diferentes tejidos (G, ID e IG) observadas en los análisis UPGMA se verificaron por medio de un análisis de componentes principales (PCA) (Figura 4).

De acuerdo con la matriz binaria de datos sobre la presencia (1) y ausencia (0) de bandas, se detectaron 36 bandas en los geles de la gónada. Se calculó una matriz binaria de presencia/ausencia de bandas, aplicando el coeficiente de similitud de Dice, y se utilizó para realizar un análisis de similitud (ANOSIM por sus siglas en inglés) basado en el coeficiente de Bray-Curtis, que permite realizar pruebas de significancia de los grupos de datos (Hammer et al., 2001). Se encontraron diferencias significativas entre las muestras asociadas con la fracción cultivable "C" y la fracción directa " $\mathrm{D}$ " [ $\mathrm{R}=0.868$ (Bray Curtis) y (Jaccard), $(P<0,004$ en ambos análisis $)]$. Además, se demostraron las diferencias entre la composición de la comunidad bacteriana de la fracción cultivable de las muestras individuales y la de las combinadas (Figura 4 A). El Indice de Shannon (H`) mostró una diferencia entre las comunidades bacterianas asociadas con la fracción cultivable "C" y la fracción directa "D" (Tabla 3). Además, el análisis mostró que las poblaciones bacterianas asociadas con las muestras individuales de tejido de la gónada están menos relacionadas que las obtenidas a partir de las muestras combinadas de tejido de la gónada, siendo cierto para ambas fracciones.
$44.6 \%$, respectively (Figure 3B). Group A is comprised of hindgut and foregut samples from both cultivable and direct fraction, however, two subgroups were also formed according to the fraction where the samples came from (Figure 3B, subgroup 1 and 2). Group B clustered two individual samples (DFI2 and DFI16) and one pool (DFP5) from the direct fraction of the foregut with a similarity percentage of $45 \%$. Group C contained all samples from the direct fraction of the hindgut, with a similarity percentage higher than $50 \%$. In cluster D the samples from cultivable fraction were grouped with similarity percentages of $38.9 \%$ and $44.6 \%$ respectively, and a high similarity percentage was observed in the bacterial population from the foregut. Furthermore, the samples from direct fractions were clustered mainly in the groups B, C and E, with a similarity of 45, 50 and $33.1 \%$, respectively. Group E contained hindgut and foregut samples from direct fractions, with similarity levels higher than $33.1 \%$.

Variations in bacterial communities on different tissue ( $\mathrm{G}, \mathrm{F}$, and $\mathrm{H}$ ) observed in the UPGMA analyses, were verified through a principal component analyses PCA (Figure 4).

According to the binary matrix of data on the presence (1) and absence (0) of bands, 36 bands were detected on the gels of the gonad. A band-based binary presence/absence matrix was calculated by applying the Dice similarity coefficient and used for an analysis of similarity (ANOSIM) based on the Bray-Curtis coefficient, which enables significance testing of the data groups (Hammer et al., 2001). Significant differences were found between the samples associated with "C" cultivable and " $\mathrm{D}$ " direct fraction $[\mathrm{R}=0.868$ (Bray Curtis) and (Jaccard), $(P<0.004$ in both analyses)]. Moreover, differences between bacterial community compositions of the cultivable fraction of individual samples and pools were demonstrated (Figure 4A). The Shannon Index $\left(\mathrm{H}^{\prime}\right)$ analysis showed a difference between the bacterial communities associated with " $\mathrm{C}$ " cultivable and " $\mathrm{D}$ " direct fraction (Table 3). Also, the analysis showed that bacterial populations associated with individual gonad tissue samples are less related than those obtained from pools of gonad tissue and that this is true for both fractions. 


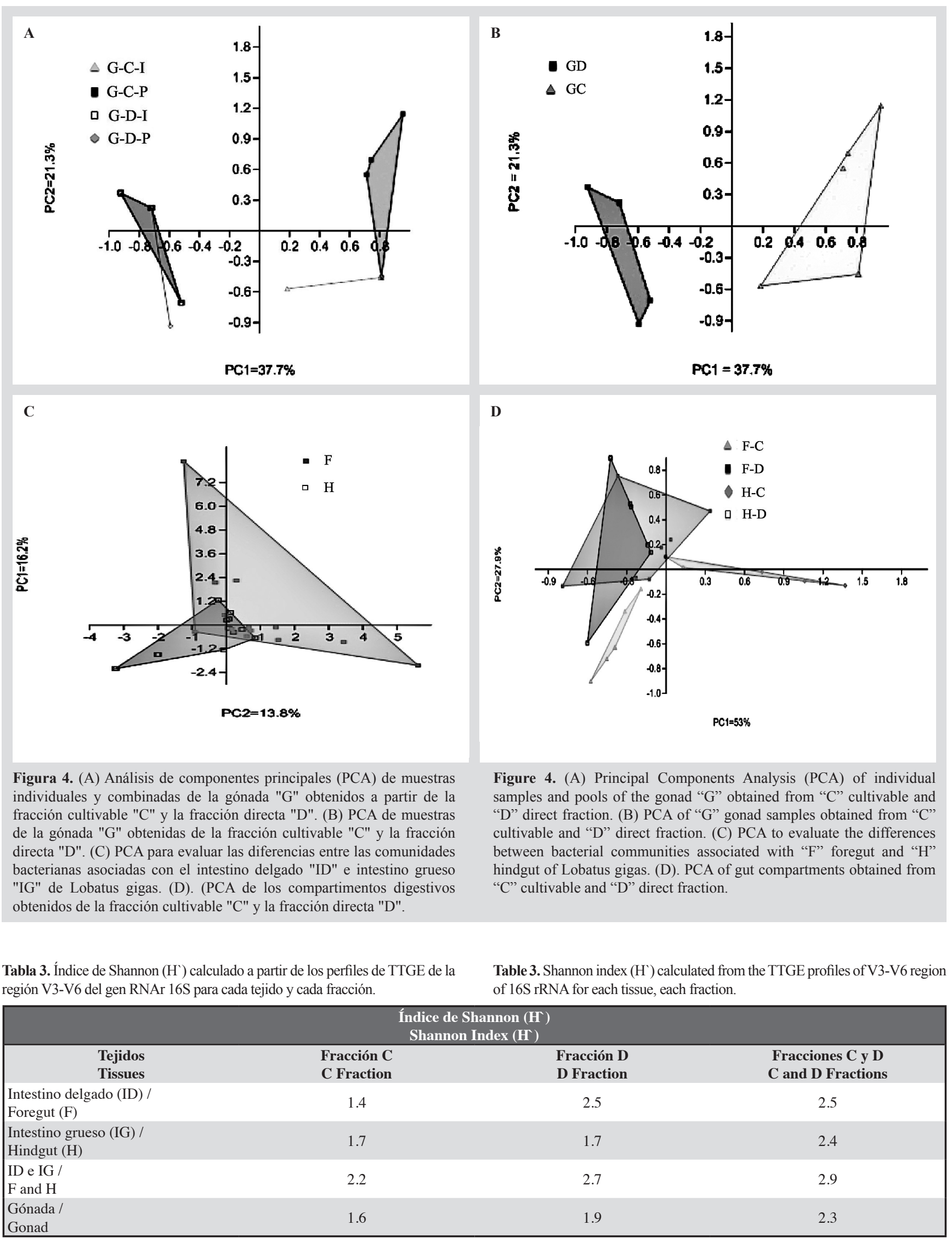


Además, se determinaron los resultados del análisis de 69 bandas en los geles del tejido intestinal. El PCA observado en la Figura 4C y el análisis de similitud (ANOSIM) mostraron diferencias significativas en la comunidad bacteriana asociada con el intestino delgado (ID) e intestino grueso (IG) $[\mathrm{R}=0.1406 \mathrm{y}$ (Bray Curtis) $\mathrm{y}$ (Jaccard), $(P<0.0018$ en ambos análisis $)]$. Las diferencias entre las comunidades bacterianas relacionadas con las fracciones cultivable y directa de cada compartimento se observan en el PCA (Figura 4D). Se encontraron diferencias significativas entre las muestras asociadas con la fracción cultivable "C" y la fracción directa " $\mathrm{D}$ " del intestino delgado (ID) $[\mathrm{R}=0.3479$ (Jaccard) y $\mathrm{R}=0.3479$ (Bray-Curtis), $(P<0.0024$ en ambos análisis)], y el intestino grueso (IG) $[\mathrm{R}=0.4643$ (Jaccard) y $\mathrm{R}=0.4643$ (Bray Curtis), $(P<0.0003)]$.

Los valores de $\mathrm{H}^{`}$ calculados a partir de G, ID e IG (teniendo en cuenta las fracciones $\mathrm{C}$ y D) revelaron que el intestino delgado tiene la comunidad bacteriana más diversa, mientras que la gónada tiene la menos diversa. Cuando se calculó H' para cada tejido y para C y D por separado, fue posible observar que la diversidad es mayor en la fracción D que en la fracción C, excepto en el tejido del intestino grueso que mantuvo la diversidad en las dos fracciones (Tabla 3).

La secuenciación y el análisis filogenético de las bandas $(\approx 400 \mathrm{pb})$ obtenidas del gel TTGE revelaron varios grupos filogenéticos diferentes para cada tejido analizado (gónada, intestino delgado e intestino grueso) de acuerdo a su similitud con las secuencias del gen RNAr 16S en bases de datos públicas (Tabla 4, Figura 5). Estos pertenecían a Alphaproteobacteria, Gammaproteobacteria y Bacilli (Tabla 4, Figura 5A) para la gónada, y la especie más común fue Ralstonia pikettii, que se observó tanto en la fracción cultivable como en la directa (Figura 4A). En los compartimentos digestivos, los resultados de las secuencias parciales del gen 16S rRNA revelaron una gran similitud con las bacterias pertenecientes a Alphaproteobacteria (12.5\%), Betaproteobacteria (12.5\%), Gammaproteobacteria (12.5\%), Bacilli (31.25\%), Clostridia (6.25\%), Actinobacteria (6.25\%), Mollicutes (6.25\%) y Deinococci (6.25\%), y bacterias no clasificadas (Tabla 4, Figura 5B).
Furthermore, the results of the analysis shownthat 69 bands were detected on the gels of the gut tissue. PCA observed in figure $4 \mathrm{C}$ and the analysis of similarity (ANOSIM), showed significant differences in the bacterial community associated with the foregut (F) and hindgut $(\mathrm{H})[\mathrm{R}=0.1406$ and (Bray Curtis) and (Jaccard), $(P<0.0018$ in both analyses $)]$. The differences among bacterial communities related to cultivable and direct fraction from each compartment is observed in the PCA (Figure 4D). Significant differences were found between the samples associated with "C" cultivable and " $\mathrm{D}$ " direct fraction of the foregut $(\mathrm{F})[\mathrm{R}=0.3479$ (Jaccard) and $\mathrm{R}=0.3479$ (Bray-Curtis), $(P$ value $<0.0024$ in both analyses) $]$, and hindgut $(\mathrm{H})[\mathrm{R}=0.4643$ (Jaccard) and $\mathrm{R}=0.4643$ (Bray Curtis), $(P$ value $<0.0003)]$.

The $\mathrm{H}^{\prime}$ values calculated from $\mathrm{G}, \mathrm{F}$, and $\mathrm{H}$ (taking into account $\mathrm{C}$ and $\mathrm{D}$ fraction) revealed that the foregut has the most diverse bacterial community while the gonad has the least diverse. When $\mathrm{H}^{`}$ was calculated for each tissue and for $\mathrm{C}$ and $\mathrm{D}$ separately, it was possible observe that the diversity is higher in $\mathrm{D}$ fraction than the $\mathrm{C}$ fraction, except for hindgut tissue which kept its diversity for both approaches (Table 3 )

Sequencing and phylogenetic analysis of the bands $(\approx 400 \mathrm{bp}$ ) excised from TTGE gel revealed several different phylogenetic groups for each sampling tissue (gonad, foregut and hindgut) according to their similarity with 16S rRNA gene sequences held in public databases (Table 4, Figure 5). These belonged to Alphaproteobacteria, Gammaproteobacteria and Bacilli (Table 4, Figure 5A) for the gonad, and the most common species was Ralstonia pikettii, which was observed in both cultivable and direct fraction (Figure 4A). In the gut compartments, the results of partial sequences of the 16S rRNA gene revealed high similarity with bacteria belonging to Alphaproteobacteria (12.5\%), Betaproteobacteria (12.5\%), Gammaproteobacteria (12.5\%), Bacilli (31.25\%), Clostridia (6.25\%), Actinobacteria (6.25\%), Mollicutes (6.25\%) and Deinococci (6.25\%) and unclassified bacteria (Table 4, Figure 5B). 
Tabla 4. Afiliaciones taxonómicas de las secuencias parciales de ADN obtenidas de los perfiles TTGE de la gónada, intestino delgado e intestino grueso de L. gigas.
Table 4. Taxonomic affiliations of DNA partial sequences obtained from TTGE bands of L. gigas gonad, foregut, and hindgut.

\begin{tabular}{|c|c|c|c|c|c|c|}
\hline $\begin{array}{l}\text { Origen } \\
\text { Origin }\end{array}$ & $\begin{array}{l}\text { Banda TTGE } \\
\text { TTGE Band }\end{array}$ & $\begin{array}{l}\mathbf{N}^{\circ} \text { de acceso } \\
\text { Accession } \mathbf{N}^{\circ}\end{array}$ & $\begin{array}{c}\text { Porcentaje de similitud } \\
\text { (BlastN) } \\
\text { Percent Similarity } \\
\text { (BlastN) }\end{array}$ & $\begin{array}{l}\text { Filo } \\
\text { Affiliation } \\
\text { Phylum }\end{array}$ & $\begin{array}{l}\text { Clase } \\
\text { Class }\end{array}$ & $\begin{array}{l}\text { Secuencia más } \\
\text { cercana } \\
\text { Closest sequence }\end{array}$ \\
\hline DIDI6 / DFI6 & $4 \mathrm{~F}$ & KX891442 & $93 \%$ & & $\alpha$-Proteobacteria & $\begin{array}{l}\text { Oceanicola marinus. } \\
\text { NR_043969.1 }\end{array}$ \\
\hline DIDP1 / DFP1 & $9 \mathrm{~F}$ & KX891443 & $98 \%$ & & $\beta$-Proteobacteria & $\begin{array}{c}\text { Undibacterium } \\
\text { oligocarboniphilum. } \\
\text { NR_117348.1 }\end{array}$ \\
\hline DIDI3 / DFI3 & $3 \mathrm{~F}$ & KX891440 & $97 \%$ & Proteobacteria & & \\
\hline DIGP3 / DPH3 & Clon $38 \mathrm{H}$ & KX891439 & $98 \%$ & & & \\
\hline CIGP5 / CHP5 & $\mathrm{AH}$ & KX891445 & $99 \%$ & & $\gamma$-Proteobacteria & $\begin{array}{l}\text { Pseudomonas } \\
\text { azotoformans. } \\
\text { NR_113600.1 }\end{array}$ \\
\hline DIGI16 / DHI16 & Clon $31 \mathrm{H}$ & KX891438 & $99 \%$ & & & $\begin{array}{l}\text { Pantoea stewartii. } \\
\text { NR_104928.1 }\end{array}$ \\
\hline DIDP3 / DFP3 & Clon 18F & KX891432 & $95 \%$ & Firmicutes & Clostridia & $\begin{array}{c}\text { Clostridium } \\
\text { straminisolvens. } \\
\text { NR_024829.1 }\end{array}$ \\
\hline DIDP4 / DFP4 & $21 \mathrm{~F}$ & KX891442 & $100 \%$ & & Bacilli & $\begin{array}{l}\text { Streptococcus sanguinis. } \\
\text { NR_113260.1 }\end{array}$ \\
\hline DIGI6 / DHI6 & $29 \mathrm{H}$ & KX891431 & $100 \%$ & & & $\begin{array}{l}\text { Streptococcus sanguinis. } \\
\text { NR_074974.1 }\end{array}$ \\
\hline DIGI3 / DHI3 & Clon $28 \mathrm{H}$ & KX891436 & $100 \%$ & & & $\begin{array}{l}\text { Streptococcus mitis. } \\
\quad \text { NR_116207.1 }\end{array}$ \\
\hline CIDI2 / CFI2 & $\mathrm{ZF}$ & KX891444 & $96 \%$ & & & $\begin{array}{l}\text { Anoxibacillus } \\
\text { amylolyticus. } \\
\text { NR_042225.1 }\end{array}$ \\
\hline DIDI2 / DFI2 & $2 \mathrm{~F}$ & KX891437 & $100 \%$ & & & $\begin{array}{l}\text { Bacillus cereus. } \\
\text { NR_074540.1 }\end{array}$ \\
\hline \multirow[t]{2}{*}{ DIGI2 / DHI2 } & Clon 24H & KX891434 & $99 \%$ & Actinobacteria & Actinobacteria & $\begin{array}{l}\text { Propionibacterium acnes. } \\
\text { NR_040847.1 }\end{array}$ \\
\hline & $26 \mathrm{H}$ & KX891435 & $88 \%$ & $\begin{array}{l}\text { Deinococcus- } \\
\text { Thermus }\end{array}$ & Deinococci & $\begin{array}{l}\text { Deinococcus } \\
\text { geothermalis. } \\
\text { NR_074342.1 }\end{array}$ \\
\hline DIGP5 / DHP5 & $42 \mathrm{H}$ & KX891441 & $88 \%$ & Tenericutes & Mollicutes & $\begin{array}{c}\text { Mycoplasma neophronis. } \\
\text { NR_108494.1 }\end{array}$ \\
\hline DIDP1 / DFP1 & Clon 10F & $\begin{array}{l}\text { Secuencia de la } \\
\text { quimera }\end{array}$ & $93 \%$ & Spirochaetae & Spirochaetia & $\begin{array}{l}\text { Spirochaeta litoralis. } \\
\text { NR_104732.1 }\end{array}$ \\
\hline \multirow[t]{4}{*}{ CGI4 / CGI4 } & G1 & KX891446 & $96 \%$ & & & $\begin{array}{l}\text { Ralstonia pickettii. } \\
\text { NR_043152.1 }\end{array}$ \\
\hline & & & $96 \%$ & & & $\begin{array}{l}\text { Ralstonia pickettii. } \\
\text { NR_102967.1 }\end{array}$ \\
\hline & G8 & KX891447 & $96 \%$ & & $\beta$-Proteobacteria & $\begin{array}{l}\text { Ralstonia pickettii. } \\
\text { NR_043152.1 }\end{array}$ \\
\hline & & & $96 \%$ & & & $\begin{array}{l}\text { Ralstonia mannitolilytica. } \\
\quad \text { NR_025385.1 }\end{array}$ \\
\hline \multirow[t]{2}{*}{ DGP5 / DGP5 } & Clon G38 & KX886796 & $99 \%$ & Proteobacteria & & $\begin{array}{l}\text { Ralstonia pickettii. } \\
\text { NR_043152.1 }\end{array}$ \\
\hline & & & $98 \%$ & & & $\begin{array}{l}\text { Ralstonia mannitolilytica. } \\
\text { NR_025385.1 }\end{array}$ \\
\hline \multirow[t]{2}{*}{ CGP5 / CGP5 } & $\mathrm{G} 22$ & KX891450 & $95 \%$ & & $\alpha$-Proteobacteria & $\begin{array}{l}\text { Roseomonas aquatica. } \\
\text { NR_042501.1 }\end{array}$ \\
\hline & & & $94 \%$ & & & $\begin{array}{l}\text { Roseomonas vinacea. } \\
\text { NR_044191.1 }\end{array}$ \\
\hline \multirow[t]{2}{*}{ CGP4 / CGP4 } & $\mathrm{G} 21$ & KX886797 & $83 \%$ & Firmicutes & Bacilli & $\begin{array}{l}\text { Bacillus gotheilli. } \\
\text { NR_108491.1 }\end{array}$ \\
\hline & & & $83 \%$ & & & $\begin{array}{l}\text { Bacillus foraminis. } \\
\text { NR_042274.1 }\end{array}$ \\
\hline \multirow[t]{2}{*}{ DGP2 / DGP2 } & G32 & KX891449 & $94 \%$ & & & $\begin{array}{l}\text { Bacillus lichenoformis. } \\
\text { NR_074923.1 }\end{array}$ \\
\hline & & & $94 \%$ & & & $\begin{array}{l}\text { Bacillus shackletonii. } \\
\text { NR_025373.1 }\end{array}$ \\
\hline
\end{tabular}


A

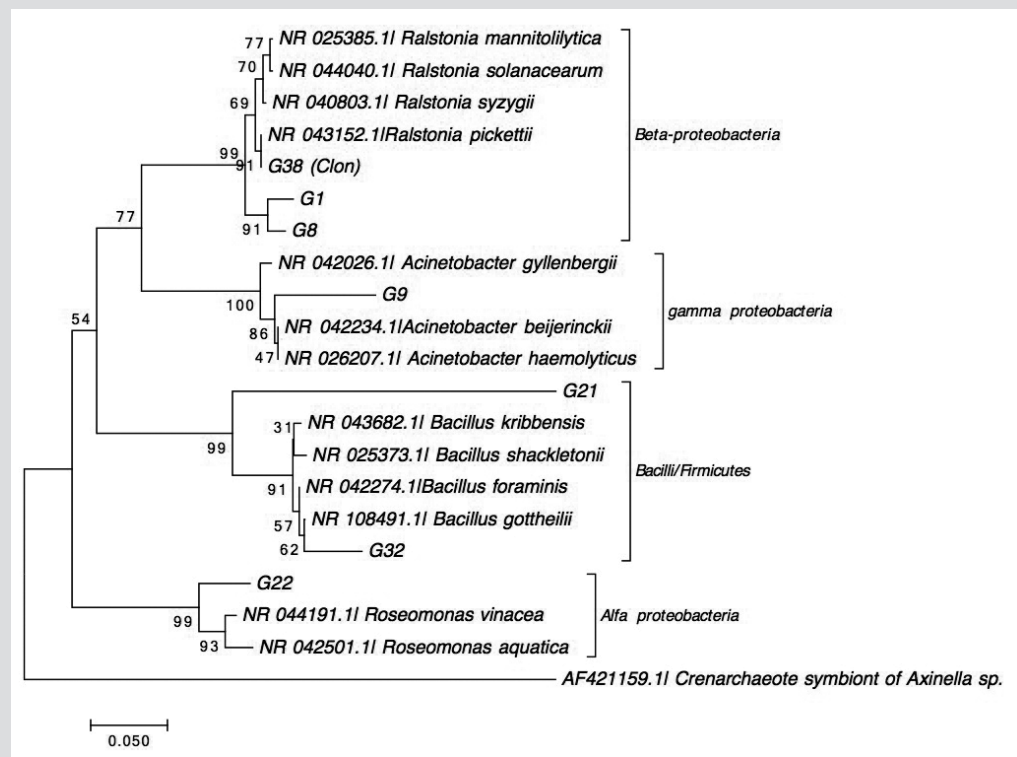

B

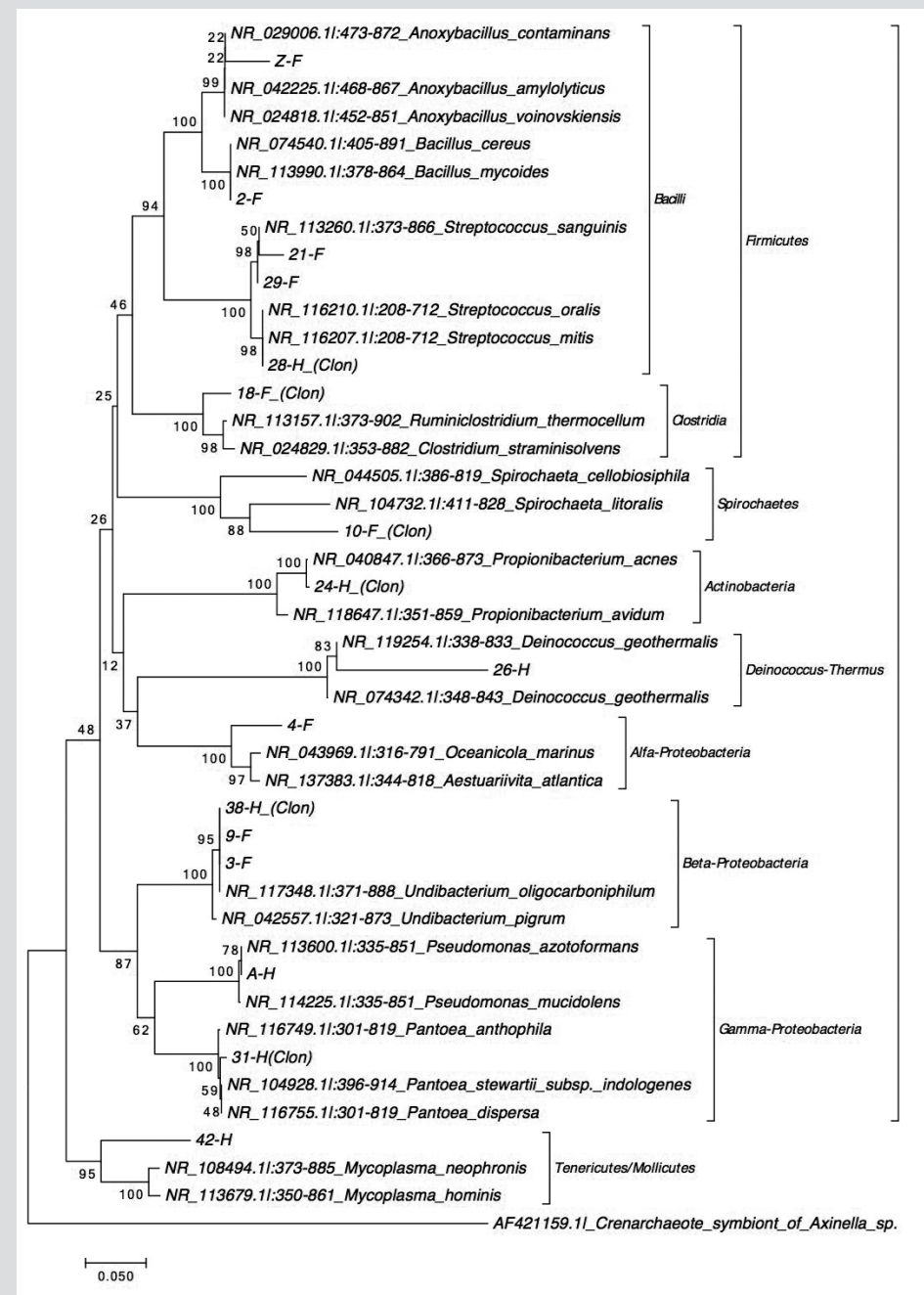

Figura 5. Dendrograma basado en el gen RNAr 16S que muestra las relaciones filogenéticas de los perfiles de TTGE obtenidos a partir de las muestras de ADN total de la gónada "G" (A) y del intestino delgado " ID", "IG" del intestino grueso (B) de L. gigas.
Figure 5. 16S rRNA gene-based dendogram showing the phylogenetic relationships of TTGE bands obtained from the total DNA samples from the "G" gonad (A) and " $F$ " foregut, " $H$ " hindgut (B) of L. gigas. 


\section{DISCUSIÓN}

Estudios recientes han caracterizado la microbiota de L. gigas del Caribe colombiano, con el objetivo de estudiar la diversidad bacteriana asociada con los caracoles silvestres y cautivos (Acosta et al., 2009; Rodriguez et al., 2011; Pérez et al., 2014). En este estudio, realizamos una de las primeras investigaciones exploratorias en diferentes tejidos para examinar la comunidad bacteriana dominante en $L$. gigas. Analizamos la composición bacteriana de la gónada y el intestino (delgado y grueso) del caracol rosado de la Reserva de la Biosfera de Seaflower mediante el uso de diferentes métodos microbiológicos y moleculares. Cuando comparamos las bacterias cultivadas, el enfoque molecular basado en el análisis del extracto de ADN directamente obtenido de la muestra parece ser una estrategia complementaria para determinar los componentes principales en la comunidad microbiana del caracol rosado.

El análisis realizado utilizando las técnicas de cultivo convencionales, tales como el recuento de UFC en agar marino y TCBS, nos permitió establecer la presencia de bacterias heterotróficas y bacterias pertenecientes a la familia Vibrionacea en la gónada y en los compartimentos digestivos del caracol rosado. El recuento en agar TCBS sugiere una abundancia de vibrios con un total de $2.83 \times 10^{7}$ UFC por gramo de tejido gonadal y $1.01 \times 10^{7}$ UFC por gramo de tejido para los compartimentos digestivos analizados; sin embargo, hasta la fecha no hay estudios que hayan descrito la microbiota gonadal del caracol rosado. Previamente, Avendaño-Herrera et al. (2001) reportaron una carga de bacterias heterotróficas en la gónada del bivalvo Argopecten purpuratus cautivo; obtuvieron un recuento de $4 \times 10^{4}$ UFC por gramo y un recuento de Vibrionacea de $3 \times 10^{2}$ UFC por gramo. Nuestros resultados contrastan con los descritos por Avendaño-Herrera et al. (2001) lo que podría deberse a las condiciones de cautividad bajo las cuales se realizaron los estudios de $A$. purpuratus. La afinidad de los vibrios por el tejido de la gónada se ha descrito previamente en el molusco Crassostrea gigas y se ha relacionado con los episodios de mortalidad de esta especie (De Decker et al., 2011). Se necesitan estudios destinados a establecer la identidad de los vibrios asociados con la gónada, el intestino delgado e intestino grueso y sus posibles efectos sobre el desarrollo de los moluscos. Además, las bacterias pertenecientes a la familia Enterobacteriaceae y los géneros Aeromonas y Pseudomonas pueden desarrollarse en el medio TCBS, y podrían interferir con los recuentos bacterianos, generando una sobreestimación en la abundancia total de vibrios presentes en el tejido analizado.

\section{DISCUSSION}

L. gigas microbiota from the Colombian Caribbean has been characterized by recent studies, with the goal of study the bacterial diversity associated with both wild and captive conchs (Pérez et al., 2014; Acosta et al., 2009; Rodriguez et al., 2011). In this study we conduct one of the first exploratory investigations into consideration the different tissues to observe the dominant bacterial community in of L. gigas. We analyzed the bacterial composition of the gonad and the gut (foregut and hindgut) of the wild queen conch from the Seaflower biosphere reserve by using different microbiological and molecular methods. When we compared the cultured bacteria and a molecular approach based on analysis of DNA extract direct from the sample seems to be a complementary strategy to determine the principal components in the microbial community of queen conch.

The analysis performed using conventional culture techniques, such as counting CFUs in marine and TCBS agar, allowed us to establish the presence of heterotrophic bacteria and bacteria belonging to the family Vibrionacea in the gonad and in the gut compartments of the queen conch. The TCBS agar count suggests an abundance of vibrios with a total of $2.83 \times 10^{7} \mathrm{CFUs}$ per gram in gonad tissue and $1.01 \times 10^{7} \mathrm{CFUs}$ per gram of tissue for the gut compartments analyzed; nevertheless, to date no studies have described the gonad microbiota of the conch. Previously, Avendaño-Herrera et al. (2001) reported a load of heterotrophic bacteria in the bivalve Argopecten purpuratus gonad in captivity; they counted 4 x $10^{4}$ CFUs per gram and a Vibrionacea count of $3 \times 10^{2}$ CFUs per gram. Our results contrast with those describe by Avendaño-Herrera et al. (2001) and could be due to the captivity conditions under which the $A$. purpuratus studies were performed. The affinity of vibrios to the gonad tissue has been previously described in the mollusk Crassostrea gigas and it has been related to episodes of mortality of this species (De Decker et al., 2011). Studies aimed at establishing the identity of vibrios associated with the gonad, foregut and hindgut and its possible effects on mollusk development are necessary. Also, the bacteria belonging to the family Enterobacteriaceae and the genera Aeromonas and Pseudomonas can develop in the TCBS medium, and they could interfere with bacterial counts, generating an overestimation in the total vibrio abundance present in the tissue analyzed. 
El análisis de los perfiles de TTGE mostró comunidades bacterianas similares entre las muestras individuales y las combinadas en el tejido de la gónada (Figura 2A), con predominio de dos o tres bandas por perfil. Estos resultados podrían estar relacionados con las bacterias autóctonas de este tejido del molusco. Las diferencias en los perfiles de bandas observados entre las muestras individuales y combinadas de la gónada, el intestino delgado e intestino grueso se verificaron con un PCA. El análisis sugiere con fuerza que hay una mayor diferencia en las poblaciones bacterianas asociadas con las muestras individuales que las asociadas con las muestras combinadas de ambas fracciones (C y D) (Figura 3). Se han reportado resultados similares en diferentes estudios con organismos marinos. En estos estudios, se observó una variación individual incluso entre los peces criados en condiciones ambientales similares, con antecedentes genéticos similares y alimentados con la misma dieta, lo que pone de relieve la influencia del hospedador en la diversidad bacteriana (Spor et al., 2011; McKnite et al., 2012; Navarrete et al., 2012). Además de esto, los perfiles de las muestras combinadas fueron similares en algunas muestras, lo que sugiere la presencia de una población bacteriana dominante en estos tejidos. Sin embargo, estos resultados podrían llevar a conclusiones sesgadas, debido a la posibilidad de que las bacterias dominantes presentes en un individuo en particular puedan interpretarse como bacterias comunes para todos los individuos analizados en la muestra (Reveco et al., 2014).

Por otro lado, los resultados revelaron la presencia de una comunidad más compleja y diversa asociada con el intestino delgado del caracol rosado en comparación con el intestino grueso. También se observaron cambios importantes en la estructura de la comunidad bacteriana entre la fracción cultivable (C) y la fracción directa (D). $\mathrm{Se}$ encontraron diferencias significativas entre ambos compartimentos digestivos con un porcentaje promedio de disimilitud del $94.41 \%$. Estos resultados se verificaron con el análisis de componentes principales presentado en la Figura 4C, el cual sugiere que el intestino delgado e intestino grueso han sido colonizados por diferentes comunidades bacterianas; este hecho fue respaldado por el índice de diversidad ( $\left.\mathrm{H}^{\prime}\right)$, que resultó ser mayor en el intestino delgado que en el intestino grueso (Tabla 3). Estas diferencias podrían estar asociadas con los procesos metabólicos que tienen lugar específicamente en cada compartimento. Los estudios en peces sugieren que la variación en la diversidad microbiana entre los compartimentos digestivos podría
The analysis of TTGE profiles showed similar bacterial communities among the individual and pool samples in the gonad tissue (Figure 2A), with dominance of two or three bands per profile. These results could be related with the autochthonous bacteria of this mollusk tissue. The differences in the banding profiles observed between individual and pooled samples from gonad, foregut and hindgut were verified with a PCA. The analysis highly suggests that there is a greater difference in bacterial populations associated with individual samples than those associated with pooled samples from both fractions (C and D) (Figure 3). Similar results have been reported in different studies with marine organisms. In these studies individual variation was observed even among fish raised under similar environmental conditions, with similar genetic background, and fed the same diet, emphasizing the influence of the host on bacterial diversity (Spor et al., 2011; McKnite et al., 2012; Navarrete et al., 2012). Besides this, banding patterns from pools were similar in some samples, suggesting the presence of a dominant bacterial population in these tissues. However, these results could lead to biased conclusions, due to the possibility that the dominant bacteria present in one individual could be interpreted as common bacteria for all the individuals analyzed in the sample (Reveco et al., 2014).

Meanwhile, the results revealed the presence of a more complex and diverse community associated with the conch foregut when compared to the hindgut. Important shifts in the bacterial community structure were also observed between cultivable fraction (C) and direct fraction (D). Significant differences between both gut compartments were found with an average percentage of dissimilarity of $94.41 \%$. These results were verified with the principal components analysis presented in figure $4 \mathrm{C}$, which suggests that the foregut and hindgut have been colonized by different bacterial communities, this fact was supported with diversity index $\left(\mathrm{H}^{\prime}\right)$, which showed a higher diversity in foregut than in hindgut (Table 3 ). These differences could be associated with metabolic processes carried out specifically in each compartment. Studies on fish suggest that variation in microbial diversity among gut compartments could be due to differences in $\mathrm{pH}$ and protease activity in the lumen (Yu et al., 2007; Yúfera and Darías, 2007). Furthermore, differences in the $\mathrm{pH}$ of the Epinephelus coioides fish stomach, pyloric caeca and intestine have been reported (Yu et al., 2007). These physicochemical parameters might be associated with the changes observed in the microbiota of different gut compartments, which could be related to 
deberse a diferencias en el $\mathrm{pH}$ y a la actividad de la proteasa en la luz intestinal (Yu et al., 2007; Yúfera and Darías, 2007). Además, se han reportado diferencias en el pH del estómago, ciegos pilóricos e intestino del pez Epinephelus coioides (Yu et al., 2007). Estos parámetros fisicoquímicos podrían estar asociados con los cambios observados en la microbiota de los diferentes compartimentos digestivos, que podrían estar relacionados con las funciones específicas de cada intestino y las condiciones ecológicas del hábitat donde se alimenta L. gigas.

Según el análisis filogenético, las secuencias de la gónada indicaron que la comunidad bacteriana había sido colonizada principalmente por bacterias pertenecientes al género Ralstonia, que estaban representadas por varias bandas TTGE en las fracciones directa y cultivable de las muestras individuales y combinadas (Figura 2A, Tabla 4). Este hallazgo sugiere que la gónada podría ser un sitio de simbiosis bacteriana en el caracol rosado. Aunque se sabe poco sobre la microbiota de la gónada en organismos marinos y su interacción con el hospedador, estudios previos del microbioma en mamíferos han demostrado que existe una simbiosis entre mamíferos y bacterias en el tracto reproductor y que esta interacción puede ayudar a defender al hospedador contra las infecciones y mejorar su salud reproductiva (Miller et al., 2017; Kindinger et al., 2017).

En el caso del intestino delgado e intestino grueso, el análisis filogenético reveló diferencias entre los dos compartimentos (Tabla 4 y Figura 5B). Las especies encontradas en ambos compartimentos pertenecen al phylum Firmicutes y Actinobacteria, mientras que los filos Proteobacteria, Deinococcus - Thermus, y Tenericutes solo se encontraron en el intestino grueso del caracol rosado. Estos resultados son consistentes con los reportados en muestras intestinales del caracol rosado de las Islas del Rosario (Acosta et al., 2009; Pérez et al., 2014) y en otros organismos marinos (Sun et al., 2011; Trabal et al., 2012; Chaiyapechara et al., 2012). Aunque existen diferencias en las metodologías empleadas, los resultados están relacionados con la alta diversidad bacteriana asociada con este molusco.

Las bacterias de los géneros Bacillus y Propionibacterium han sido caracterizadas como probióticos en peces y crustáceos marinos (Nakagawa et al., 2007; Lan et $a l$ et al., 2007; Cousin et al., 2010). Más específicamente, se ha establecido que el género Bacillus actúa como un agente biológico contra Aeromonas hydrophila (Lalloo et al., 2007, 2008) y los miembros de este género producen una amplia specific functions in each gut and the ecological conditions of the habitat where L. gigas feeds.

According to the phylogenetic analysis, sequences from the gonad, indicated that the bacterial community has been colonized mainly by bacteria belonging to the genus Ralstonia, which were represented by several TTGE bands in the direct and cultivable fraction of pooled and individual samples (Figure 2A, Table 4). This finding suggests that the gonad could be a site of bacteria symbiosis in the queen conch. Although little is known about gonad microbiota in marine organisms and its interaction with the host, previous studies of the microbiome in mammals have demonstrated that in the reproductive system there is a mammal-bacteria symbiosis and this interaction may help defend the host against infectious diseases and improve its reproductive health (Miller et al., 2017; Kindinger et al., 2017).

In the case of the foregut and hindgut, phylogenetic analysis revealed differences between the two compartments (Table 4 and Figure 5B). The species found in both compartments belong to the phylum Firmicutes and Actinobacteria, while the phylum Proteobacteria, Deinococcus - Thermus, and Tenericutes were only found in the conch hindgut. These results are consistent with those reported in gut samples of the queen conch from Islas del Rosario (Acosta et al., 2009; Pérez et al., 2014) and other marine organisms (Sun et al., 2011; Trabal et al., 2012; Chaiyapechara et al., 2012). Although there are differences in the methodologies employed, the results are related to a high bacterial diversity associated with this mollusk

Bacteria of the genus Bacillus and Propionibacterium have been characterized as probiotics in fish and marine crustaceans (Nakagawa et al., 2007; Lan et al et al., 2007; Cousin et al., 2010). More specifically, the genus Bacillus has been established as a biological agent against Aeromonas hydrophila (Lalloo et al., 2007, 2008) and the members of this genus produce a wide range of antagonistic compounds that have been found in the gut tract of crustaceans and fish (Balcázar et al., 2006). The presence of Pseudomonas in the foregut of the queen conch coincides with the results reported in other mollusks and in different marine organisms such as crustaceans and fish (Sfanos et al., 2005; Romero and Navarrete, 2006; Trabal et al., 2012). It is important to notice that members of this genus isolated from marine organisms have been recognized for their antibiotic activity against a broad spectrum of microorganisms (Gram, 1993; Jayatilake et al., 1996; Zheng et al., 2005). These results suggest that the presence of Pseudomonas libanensis 
gama de compuestos antagónicos que se han encontrado en el tracto digestivo de crustáceos y peces (Balcázar et al., 2006). La presencia de Pseudomonas en el intestino delgado del caracol rosado coincide con los resultados reportados en otros moluscos y en diferentes organismos marinos como crustáceos y peces (Sfanos et al., 2005; Romero and Navarrete, 2006; Trabal et al., 2012). Es importante observar que los miembros de este género, aislados de los organismos marinos, han sido reconocidos por su actividad antibiótica frente a un amplio espectro de microorganismos (Gram, 1993; Jayatilake et al., 1996; Zheng et al., 2005). Estos resultados sugieren que la presencia de Pseudomonas libanensis podría estar relacionada con efectos beneficiosos y contribuir a la supervivencia de L. gigas al defenderle de posibles patógenos que puedan afectar a su salud y desarrollo. Mientras tanto, el género Streptococcus (Tabla 4 y Figura 5B) ha sido asociado con varias enfermedades en peces y crustáceos, e identificado como el agente causante de la enfermedad del desarrollo lento del crustáceo Carcinus mediterraneus (Pappalardo y Boemare, 1982). Los géneros Undibacterium y Oceanicola encontrados en el intestino delgado e intestino grueso del caracol rosado (Tabla 4) también se han reportado recientemente en el intestino de las muestras del crustáceo silvestre Penaeus monodon (Rungrassamee et al., 2014). Resulta llamativo que Oceanicola marinus sea una especie común en ambientes marinos (Lin et al., 2007; Chunyan et al., 2012).

Se observaron diferencias entre los resultados obtenidos del análisis de las fracciones cultivable y directa en la gónada, el intestino delgado e intestino grueso del caracol rosado. Es posible que estas diferencias se deban a los métodos dependientes de cultivo-los cuales favorecen el crecimiento de bacterias capaces de crecer en medios sintéticos-independientemente de si estas bacterias son dominantes en la muestra. Se ha demostrado que estas bacterias representan sólo el $1 \%$ de la población total, lo que subestima la diversidad de las poblaciones microbianas existentes (Hansen y Olafsen, 1999; Suau et al., 1999). Otros estudios basados en métodos independientes de cultivo han demostrado una imagen menos sesgada de la población bacteriana presente en las muestras ambientales que los métodos dependientes de cultivo (Amann et al., 1995). No obstante, es necesario tener en cuenta que las técnicas basadas en genes ribosomales pueden verse afectadas por las bajas concentraciones de $\mathrm{ADN}$ en diferentes especies o la presencia de altas concentraciones de $\mathrm{ADN}$ que compiten durante las reacciones de la PCR (Ogier et al., 2002), lo could be related to beneficial effects and it could contribute to the survival of L. gigas by defending it against potential pathogens that may affect its health and development. Meanwhile, the genus Streptococcus (Table 4 and Figure 5B) has been associated with several diseases in fish and crustaceans, and it has been identified as the causative agent of the slow development disease in the crustacean Carcinus mediterraneus (Pappalardo and Boemare, 1982). The genus Undibacterium and Oceanicola found in the foregut and hindgut of the queen conch (Table 4) has also been recently reported in the gut of wild crustaceans Penaeus monodon samples (Rungrassamee et al., 2014). It is remarkable that Oceanicola marinus is a common specie in marine environments (Lin et al., 2007; Chunyan et al., 2012).

Differences between the results obtained from cultivable and direct fraction analysis were observed in the conch gonad, foregut and hindgut. It is possible that these differences are due to the culture dependent techniques which favor the growth of bacteria able to grow on synthetic media, regardless whether these bacteria are dominant in the sample. It has been shown that these bacteria represent only $1 \%$ of the total population, generating an underestimation of the actual microbial population diversity (Hansen and Olafsen, 1999; Suau et al., 1999). Further studies based on culture-independent methods have demonstrated a less biased picture of the bacterial population present in environmental samples than culture-dependent methods (Amann et al., 1995). Nonetheless, it is necessary to take into account that techniques based on ribosomal genes may be affected by low concentrations of DNA from different species or the presence of high concentrations of DNA that are competing during PCR reactions (Ogier et al., 2002), which can affect the detection of some species in the community (Kisand and Wikner, 2003). That is why; it is necessary to implement both approaches (culture-dependent and culture-independent) in the study of microbiota from natural samples, in order to recover as much information as possible about the bacterial species present in the samples analyzed (Kisand and Wikner, 2003).

This research established the bacterial community associated with gonad and foregut and hindgut of L. gigas. Regarding the gonad, the results suggest that this organ has a stable microbiota that is mainly dominated by members of the genus Ralstonia that could be endosymbionts of this tissue. Additionally, the presence of vibrios should be verified and it is necessary to determine their effect on the gonad. But, more comprehensive studies are required 
que puede afectar a la detección de algunas especies en la comunidad (Kisand y Wikner, 2003). Esta es la razón por la cual es necesario desarrollar ambos enfoques (dependientes de cultivo e independientes de cultivo) en el estudio de la microbiota a partir de las muestras naturales, con el fin de recoger la mayor cantidad de información posible sobre las especies bacterianas presentes en las muestras analizadas (Kisand y Wikner, 2003).

Esta investigación determinó la comunidad bacteriana asociada con la gónada y el intestino delgado e intestino grueso de L. gigas. Con respecto a la gónada, los resultados sugieren que este órgano tiene una microbiota estable dominada principalmente por miembros del género Ralstonia que podrían ser endosimbiontes de este tejido. Además, es necesario verificar la presencia de vibrios y determinar su efecto sobre la gónada. Aún se requieren estudios más detallados para determinar el papel que desempeña esta comunidad bacteriana en la salud y el ciclo reproductivo de L. gigas. En el caso del intestino delgado e intestino grueso, el análisis filogenético reveló diferencias entre los dos compartimentos. Sin embargo, se necesitan más estudios para establecer el efecto de estas comunidades en los diferentes compartimentos del caracol rosado. En general, los hallazgos que describimos podrían usarse para el desarrollo de estrategias para lograr aumentar la nutrición, la prevención de patógenos y contribuir a la conservación de esta especie vulnerable de la Reserva de la Biosfera de Seaflower en el Caribe colombiano.

\section{AGRADECIMIENTOS}

Agradecimientos a la Universidad Nacional de Colombia y a la Secretaría de Agricultura y Pesca del Archipiélago de San Andrés, Providencia y Santa Catalina, Isla de San Andrés, a través de los proyectos 20101009144 y 201010011106, por su apoyo financiero. De acuerdo con el marco legislativo colombiano del Ministerio del Ambiente de Colombia, este proyecto está suscrito a "Permiso Macro No. 0255 " otorgado por la Autoridad Nacional de Licencias Ambientales (ANLA) a la Universidad Nacional de Colombia el 14 de marzo de 2014. Agradecimiento especial a Erick Castro, Jaisón Cuartas y Luz Pineda por todo el apoyo técnico proporcionado y la doctora Gloria Cadavid por su apoyo incondicional. to determine the role played by this bacterial community in the health and the reproductive cycle of the L. gigas. In the case of the foregut and hindgut, phylogenetic analysis revealed differences between the two compartments. However, to establish the effect of these communities on the different compartments of the conch, further investigations are necessary. Overall, the findings reported here could be used for the development of strategies to increase nutrition, prevent pathogens and contribute to the conservation of this vulnerable species from the Seaflower Biosphere Reserve in the Colombian Caribbean.

\section{ACKNOWLEDGMENTS}

We thank to the Universidad Nacional de Colombia and Secretaría de Agricultura y Pesca del Archipiélago de San Andrés, Providencia y Santa Catalina, Isla de San Andrés, through the projects 20101009144 and 201010011106, for their financial support. According to the Colombian legislative framework of the Environmental Ministry of Colombia, this project is subscribed to "Permiso Marco No. 0255" granted by the Autoridad Nacional de Licencias Ambientales (ANLA) to the Universidad Nacional de Colombia on March 14, 2014. Special thanks to Erick Castro, Jaisón Cuartas and Luz Pineda for all technical support provided and $\mathrm{PhD}$ Gloria Cadavid for her unconditional support. 


\section{BIBLIOGRAFÍA / LITERATURE CITED}

Acosta, E.A., E. Gómez, M. Romero-Tabarez, G.E. Cadavid-Restrepo and C.X. Moreno-Herrera. 2009. Molecular identification of bacterial populations associated to queen conch (Strombus gigas)from Colombian Caribbean. Acta Biol. Col., 14: 83-96.

Amann, R.I., W. Ludwig and K.H. Schleifer. 1995. Phylogenetic identification and in situ detection of individual microbial cells without cultivation. Microbiol Rev., 59: 143 -169.

Andlid, T., R. Vazquez-Juarez and L. Gustafsson. 1998. Yeasts isolated from the intestine of Rainbow trout adhere to and grow in intestinal mucus. Mol. Mar. Biol. Biotechnol., 7: 115-126.

Anonymous. 1999. Report on the /Queen Conch/ Stock Assessment and Management Workshop. Belize City, Belize, 15-22. Caribbean Fisheries Management Council and CARICOM Fisheries Resources Assessment and Management Programme. http://caribbeanfmc.com/reports-sci-docs/ BelizeConchWGReportFinal.PDF. 20/06/2017

Appeldoorn, R.S. and B.Q. Rodríguez. 1994. Queen conch biology, fisheries and mariculture. Fundación Científica. Los Roques, Caracas, Venezuela. 301319.

Aranda D., C.E. Baqueiro, I. Martínez, R.I. Ochoa and T. Brulé. 2001. Reproductive patterns of Strombus gigas from Alacranes reef versus Chinchorro bank of Mexico. Gulf Caribbean Fisheries Institute, 54: 202-224.

Aranda, D.A., C.E. Baqueiro, I. Martínez, R.I. Ochoa and T. Brulé. 2003a. Gonad behavior during peak reproduction period of Strombus gigas from Banco Chinchorro. Bull. Mar. Sci., 73: 241-248.

Aranda, D.A., C.E. Baqueiro, I. Martínez, R.I. Ochoa and T. Brulé. 2003b. A review of the reproductive patterns of gastropod mollusks from Mexico. Bull. Mar. Sci., 73: 629 - 641.

Avendaño-Herrera, R.E., M. Dekovic y C.E. Riquelme. 2001. Establecimiento de bacterias benéficas en el tracto digestivo y gónada de adultos de Argopecten purpuratus (Lamarck 1819) en cultivo masivo. Rev. Biol. Mar Ocean., 36: 31- 41.

Bäckhed, F., H. Ding, T. Wang, L.V. Hooper, G.Y. Koh, A. Nagy, C.F. Semenkovich and J.I. Gordon. 2004. The gut microbiota as an environmental factor that regulates fat storage. Proc. Natl. Acad. Sci. U.S.A., 101: 15718-15723.

Balcázar, L., O. Decamp, D. Vendrell, I. De Blas and I. Ruiz-Zarzuela. 2006. Health and nutritional properties of probiotics in fish and shellfish. Microb. Ecol. Health Dis., 18: 65-70. doi:10.1080/08910600600799497

Ballesteros, F., C. García, M. Rueda, K. Gómez and Mejia. 2005. Relative. Abundance and Fishery Characterization of Queen Conch Strombus gigas (Mesogastropoda- Strombidae) in the Archipielago of San Bernardo, Colombian Caribbean. Proc. Gulf Car. Fish. Inst., 58: 393-398.

Boon, N. 2002. Evaluation of nested PCR-DGGE (denaturing gradient gel electrophoresis) with group-specific 16S rRNA primers for the analysis of bacterial communities from different wastewater treatment plants. FEMS Microbiol. Ecol., 39: 101-112. http://dx.doi.org/10.1016/s0168-6496(01)00198- 2.

Brownell, W.N. 1977. Reproduction, laboratory culture and growth of Strombus gigas, Strombus costatus and Strombus pugilis in Los Roques, Venezuela. Bull. Mar. Sci., 27: 668-680.

Castro, E., H. Bent, C. Ballesteros and M. Prada. 2007. Large pelagics in the southern section of the seaflower marine protected area, San Andres archipelago, Colombia: a fishery in expansion. Gulf Car. Res., 19: 131-139.

Catarci, C. 2004. World markets and industry of selected commercially-exploited aquatic species with an international conservation profile. FAO Fisheries Circular. No. 990. Rome, FAO.

Chaiyapechara, S., W. Rungrassamee, I. Suriyachay, Y. Kuncharin, A. Klanchui, N. Karoonuthaisiri and P. Jiravanichpaisal. 2012. Bacterial Community Associated with the Intestinal Tract of P. monodon in Commercial Farms. Microb. Ecol., 63: 938-953. doi:10.1007/s00248-011-9936-2.

Chavez, P. y C. Riquelme. 1994. Análisis de la calidad bacteriológica en reproductores de Argopecten purpuratus (Lamarck, 1819) para su uso en acuicultura. Rev. Lat. Acuicult., 43:96-99.

Chunyan, X.U., Y.A.N. Qingpi and M.A. Ying. 2012. Microorganisms colonizing surface in coastal marine water as revealed by $16 \mathrm{~S}$ rRNA gene clone library analysis. Afr. J. Microbiol. Res., 6: 7271-7277.

Cousin, F.J., D.D.G. Mater, B. Foligne and G. Jan. 2010. Dairy propionibacteria as human probiotics: A review of recent evidence. Dairy Science and Technology, 91: 1-26. doi:10.1051/dst/2010032.

Creswell, L. 1994. An historical overview of queen conch mariculture: 223-230. Appeldoorn, R.S. and B. Rodríguez. (Eds.)., Queen Conch Biology, Fisheries and Mariculture. Fund. Cient. Los Roques, Caracas. Venezuela. 223-230.

Cuartas, J., J. Alzate, C.X. Moreno-Herrera and E. Marquez. 2018. Metagenomic of orange colored protrusions from the muscle of Queen Conh Lobatus gigas (Linnaeus, 1758) PeerJ, 6:e4307. https://doi.org/10.7717/peerj.4307.

Daves, N. and J. Fields. 2004. Recent developments in CITES concerning the international trade in queen conch (Strombus gigas). Proc. Gulf. Caribb. Fish. Inst., $763-770$. 
De Decker, S., J. Normand, D. Saulnier, F. Pernet, S. Castagnet and P. Boudry. 2011. Responses of diploid and triploid Pacific oysters Crassostrea gigas to Vibrio infection in relation to their reproductive status. J Invertebr Pathol, 106: 179-191. doi:10.1016/j.jip.2010.09.003

Delgado, G.A., C.T. Bartels, R.A. Glazer, N.J. Brown-Peterson and K.J. McCarthy. 2004. Translocation as a strategy to rehabilitate the queen conch (Strombus gigas) population in the Florida Keys. Fish. Bull., 102: 278-288.

Espejo, R.T. and J. Romero. 1997. Bacterial community in copper sulfide ores inoculated and leached with solution from a commercial-scale copper leaching plant. Appl. Environ. Microbiol., 63: 1344-1348.

Espejo, R.T., C.G. Feijoo, J. Romero and M. Vásquez. 1998. PAGE analysis of the heteroduplexes formed between PCR-amplified 16S rRNA genes: estimation of sequence similarity and rDNA complexity. Microbiology, 144: 1611-1617.

García Gaona., M., M.A. Márquez. and C.X. Moreno Herrera. 2016. Characterization of bacterial diversity associated with calcareous deposits and dripwaters, and isolation of calcifying bacteria from two Colombian mines. Microbiol. Res., 182: 21-30. doi:10.1016/j.micres.2015.09.006

Gerçe, B., T. Schwartz, C. Syldatk and R. Hausmann. 2011. Differences Between Bacterial Communities Associated with the Surface or Tissue of Mediterranean Sponge Species. Microb. Ecol., 61: 769-782. doi:10.1007/s00248-011-9802-2

Gram, L. 1993. Inhibitory effect against pathogenic and spoilage bacteria of Pseudomonas strains isolated from spoiled and fresh fish. Appl. Environ. Microbiol., 59: 2197-2203.

Hall, T.A. 1999. BioEdit: a user-friendly biological sequence alignment editor and analysis program for Windows 95/98/NT. Nucleic Acids Symposium Series, 41: 95-98.

Hammer, Ø., D.A. Harper and P.D. Ryan. 2001. PAST: paleontological statistics software package for education and data analysis. Paleontol. Electr., 4:1-9. Hammer, Ø., D.A. Harper and P.D. Ryan. 2005. PAST: Palaeontological statistics, ver. 1.35. Paleontología Electrónica 4.

Hansen, G.H. and J.A. Olafsen. 1999. Bacterial Interactions in Early Life Stages of Marine Cold Water Fish. Microb. Ecol., 38: 1-26. doi:10.1007/ s002489900158

Hovda, M.B., B.T. Lunestad, R. Fontanillas and J.T. Rosnes. 2007. Molecular characterization of the intestinal microbiota of farmed Atlantic salmon (Salmo salar L.). Aquaculture, 272: 581-588, doi: 10.1016/j.aquaculture.2007.08.045

Jayatilake, G.S., M.P. Thornton, A.C. Leonard, J.E. Grimwade and B.J. Baker. 1996. Metabolites from an Antarctic sponge-associated bacterium, Pseudomonas aeruginosa. J. Nat. Prod., 59: 293-296.

Kindinger, L.M., P.R. Bennett, Y.S. Lee, J.R. Marchesi, A. Smith, S.Cacciatore, E. Holmes, J.K. Nicholson, T.G. Teoh and D.A. MacIntyre. 2017. The interaction between vaginal microbiota, cervical length, and vaginal progesterone treatment for preterm birth risk. Microbiome, 5: 6. doi:10.1186/ s40168-016-0223-9

Kirjavainen, P.V. and G.R. Gibson. 1999. Healthy gut microflora and allergy: factors influencing development of the microbiota. An. Med., 31: $288-292$.

Kisand, V. and J. Wikner. 2003. Combining Culture-Dependent and -Independent Methodologies for Estimation of Richness of Estuarine Bacterioplankton Consuming Riverine Dissolved Organic Matter. Appl. Environ. Microbiol., 69: 3607-3616. doi:10.1128/AEM.69.6.3607-3616.2003

Klussmann-Kolb, A. and G.D. Brodie. 1999. Internal storage and production of symbiotic bacteria in the reproductive system of a tropical marine gastropod. Mar. Biol., 133: 443-447.

Kowalik, G., M. Davis, A. Shawl, R.A. Glazer, G.A. Delgado and C. Evans. 2006. Metamorphic response of queen conch (Strombus gigas) larvae exposed to sediment and water from nearshore and offshore sites in the Florida Keys.: Proc. Gulf Caribb. Fish. Inst., 717-729.

Lalloo, R., S. Ramchuran, D. Ramduth, J. Görgens and N. Gardiner. 2007. Isolation and selection of Bacillus spp. as potential biological agents for enhancement of water quality in culture of ornamental fish: Isolation and selection of Bacillus spp. as potential biological agents. J. Appl. Microbiol., 103: 1471-1479. doi:10.1111/j.1365-2672.2007.03360.x

Lalloo, R., D. Maharajh, J. Görgens and N. Gardiner. 2008. Functionality of a Bacillus cereus biological agent in response to physiological variables encountered in aquaculture. Appl. Microbiol. Biotechnol., 79: 111-118. doi:10.1007/s00253-008-1403-8

Lan, A., A. Bruneau, C. Philippe, V. Rochet, A. Rouault, C. Hervé, N. Roland, S. Rabot, and G. Jan. 2007. Survival and metabolic activity of selected strains of Propionibacterium freudenreichii in the gastrointestinal tract of human microbiota-associated rats. Br. J. Nutr., 97: 714. doi:10.1017/ S0007114507433001

Landínez-García, R.M., J.D. Rangel-Medrano, E.R. Castro-González y E. Márquez. 2011. Variación genética temporal del caracol pala (Strombus gigas) evidenciada por microsatélites en el atolón Bolívar, Archipiélago de San Andrés, Providencia y Santa Catalina. Cuadernos del Caribe, $14:$ 75-82.

Li, M., H. Yang and J.D. Gu. 2009. Phylogenetic Diversity and Axial Distribution of Microbes in the Intestinal Tract of the Polychaete Neanthes glandicincta. Microb. Ecol., 58: 892-902. doi:10.1007/s00248-009-9550-8

Lin, K.-Y., S. Y. Sheu, P. S. Chang, J. C. Cho and W. M. Chen. 2007. Oceanicola marinus sp. nov., a marine alpha proteobacterium isolated from seawater collected off Taiwan. Int. J. Syst. Evol. Microbiol., 57: 1625-1629. doi:10.1099/ijs.0.65020-0

Márquez, E., R.M. Landínez-García, S.P. Ospina-Guerrero, J. Aicardo, M.P. Segura, E. Castro, J.L. Correa and C. Borda. 2012. Genetic analysis of queen conch Strombus gigas from South West Caribbean. Proc. Gulf Car. Fish. Inst., 114-121. 
McCracken, V.J., J.M. Simpson, R.I. Mackie and H.R. Gaskins. 2001. Molecular ecological analysis of dietary and antibiotic-induced alterations of the mouse intestinal microbiota. J. Nutr., 131: 1862-1870.

McKnite, A.M., M.E. Perez-Munoz, L. Lu, E.G. Williams, S. Brewer, P.A. Andreux, J.W.M. Bastiaansen, X. Wang, S.D. Kachman, J. Auwerx, R.W. Williams, A.K. Benson, D.A. Peterson, and D.C. Ciobanu. 2012. Murine Gut Microbiota Is Defined by Host Genetics and Modulates Variation of Metabolic Traits. PLoS ONE, 7: e39191. doi:10.1371/journal.pone.0039191

Merrifield, D. and E. Ringø. 2014. Aquaculture nutrition: gut health, probiotics, and prebiotics. Chapter. The gut microbiota of fish, 4:75-94.

Miller, E.A., J.A. Livermore, S.C. Alberts, J. Tung and E.A. Archie. 2017. Ovarian cycling and reproductive state shape the vaginal microbiota in wild baboons. Microbiome, 5: 8. doi:10.1186/s40168-017-0228-z

Mohammadi, S.A. and B.M. Prasanna. 2003. Analysis of genetic diversity in crop plants—salient statistical tools and considerations. Crop Science, 43: $1235-1248$.

Nakagawa, H., M. Sato and D.M. Gatlin. 2007. Dietary supplements for the health and quality of cultured fish. Chapter. Microorganisms, $7: 94$ - 100.

Navarrete, P., F. Magne, C. Araneda, P. Fuentes, L. Barros, R. Opazo, R. Espejo and J. Romero. 2012. PCR-TTGE Analysis of 16S rRNA from Rainbow Trout (Oncorhynchus mykiss) Gut Microbiota Reveals Host-Specific Communities of Active Bacteria. PLoS ONE, 7:e31335. doi:10.1371/journal. pone. 0031335

Nei, M. and W.H. Li. 1979. Mathematical model for studying genetic variation in terms of restriction endonucleases. Proc. Natl. Acad. Sci. U.S.A., 76: $5269-5273$.

Ó Cuív, P., D. Aguirre de Cárcer, M. Jones, E.S. Klaassens, D.L. Worthley, V.L.J. Whitehall, S. Kang, C.S. McSweeney, B.A. Leggett and M. Morrison. 2011. The Effects from DNA Extraction Methods on the Evaluation of Microbial Diversity Associated with Human Colonic Tissue. Microb. Ecol., 61: 353-362. doi:10.1007/s00248-010-9771-x

Ogier, J.-C., O. Son, A. Gruss, P. Tailliez and A. Delacroix-Buchet. 2002. Identification of the Bacterial Microflora in Dairy Products by Temporal Temperature Gradient Gel Electrophoresis. Appl. Environ. Microbiol., 68: 3691-3701. doi:10.1128/AEM.68.8.3691-3701.2002

Pappalardo, R. and N. Boemare. 1982. An intracellular Streptococcus, causative agent of a slowly developing disease in the Mediterranean crab, Carcinus mediterraneus. Aquaculture, 28: 283-292.

Pérez, O.M., M. Posada Elorza, G.E. Cadavid Restrepo and C.X. Moreno Herrera. 2014. Assessment of the bacterial community diversity associated with the queen conch Strombus gigas (Linnaeus, 1758) from the Caribbean coast of Colombia using denaturing gradient gel electrophoresis and culturing. Aquacult. Res., 45: 773-786. doi:10.1111/are.12016

Prada, M., E. Castro, E. Taylor, V. Puentes, R. Appeldoorn and N. Daves. 2008. Non-detrimental findings for the Queen Conch (Strombus gigas) in Colombia, in: NDF Workshop Case Studies WG. https://cites.org/sites/default/files/ndf_material/WG9-CS3-S.pdf.

Rademaker, J.L. and F.J. De Bruijn. 2008. Section 7 update: Computer-assisted analysis of molecular fingerprint profiles and database construction: 13971446. In: Molecular Microbial Ecology Manual. Springer. 3299-3347.

Rawls, J.F., B.S. Samuel and J.I. Gordon. 2004. Gnotobiotic zebrafish reveal evolutionarily conserved responses to the gut microbiota. Proc. Natl. Acad. Sci. U.S.A., 101: 4596-4601.

Reed, S.E. 1996. Reproductive anatomy and biology of the genus Strombus in the Caribbean: I. Females. Proc. Gulf Car. Fish. Inst., 44: 413-426.

Reid, G., J.A. Younes, H.C. Van der Mei, G.B. Gloor, R. Knight and H.J. Busscher. 2011. Microbiota restoration: natural and supplemented recovery of human microbial communities. Nat. rev. Microbiol., 9: 27-38. doi:10.1038/nrmicro2473

Reveco, F.E., M. Øverland, O.H. Romarheim and L.T. Mydland. 2014. Intestinal bacterial community structure differs between healthy and inflamed intestines in Atlantic salmon (Salmo salar L.). Aquaculture, 15: 262-269. doi:10.1016/j.aquaculture.2013.11.007

Riquelme, C., G. Hayashida, N. Vergara, A. Vasquez, Morales and P. Chavez. 1995a. Bacteriology of the scallop Argopecten purpuratus (Lamarck, 1819) cultured in Chile. Aquaculture, 138:40-60.

Rodriguez, A.I., H. Hariharan and S. Nimrod. 2011. Occurrence and antimicrobial drug resistance of potential bacterial pathogens from shellfish, including Queen Conchs (Strombus gigas) and Whelks (Cittarium pica) in Grenada. Wedmed Centr. Microbiol., 2: WMC001943

Romero, J. and P. Navarrete. 2006. 16S rDNA-Based Analysis of Dominant Bacterial Populations Associated with Early Life Stages of Coho Salmon (Oncorhynchus kisutch). Microb. Ecol., 51: 422-430. doi:10.1007/s00248-006-9037-9

Rungrassamee, W., A. Klanchui, S. Maibunkaew, S. Chaiyapechara, P. Jiravanichpaisal and N. Karoonuthaisiri. 2014. Characterization of Intestinal Bacteria in Wild and Domesticated Adult Black Tiger Shrimp (Penaeus monodon). PLoS ONE, 9: e91853. doi:10.1371/journal.pone.0091853

Saitou, N. and M. Nei. 1987. The neighbor-joining method: a new method for reconstructing phylogenetic trees. Mol. Biol. Evol., 4 : 406-425

Sambrook, J. and D.W. Russell. 2002. Molecular Cloning: A Laboratory Manual 3rd ed. Chapter 6. Isolation of DNA Fragments from Polyacrylamide Gels by the Crush and Soak Method. Cold Spring Harbor Laboratory Press, New York, NY, USA. 76:484-487.

Sanguinetti, C., E. Dias Neto and A. Simpson. 1994. Rapid silver staining and recovery of PCR products separated on polyacrylamide gels. Biotechniques, 17:915-919. 
Sfanos, K., D. Harmody, P. Dang, A. Ledger, S. Pomponi, P. McCarthy and J. Lopez. 2005. A molecular systematic survey of cultured microbial associates of deep-water marine invertebrates. Syst. Appl. Microbiol., 28: 242-264. doi:10.1016/j.syapm.2004.12.002

Smith, B., S. Bodé, B.L. Petersen, T.K. Jensen, C. Pipper, J. Kloppenborg, M. Boyé, K.A. Krogfelt, and L. Mølbak. 2011. Community analysis of bacteria colonizing intestinal tissue of neonates with necrotizing enterocolitis. BMC Microbiol., 11: 1.

Sommer, F. and F. Bäckhed. 2013. The gut microbiota - masters of host development and physiology. Nat. Rev. Microbiol., 11: 227-238. doi:10.1038/ nrmicro2974

Spor, A., O. Koren and R. Ley, R. 2011. Unravelling the effects of the environment and host genotype on the gut microbiome. Nat. Rev. Microbiol., 9: 279-290. doi:10.1038/nrmicro2540

Stoner, A.W. 1996. Queen conch, Strombus gigas, in fished and unfished locations of the Bahamas: effects of a marine fishery reserve on adults, juveniles, and larval production. Fish. Bull., 94: 551-564.

Stoner, A.W. and M. Ray-Culp. 2000. Evidence for Allee effects in an over-harvested marine gastropod: density-dependent mating and egg production. Mar. Ecol. Prog. Ser., 202: 297-302.

Stoner, A.W. and J.M. Waite. 1991. Trophic biology of Strombus gigas in nursery habitats: Diets and food sources in seagrass meadows. J. Molluscan Stud., 57: 451-460.

Suau, A., R. Bonnet, M. Sutren, J.-J. Godon, G.R. Gibson, M.D. Collins and J. Doré. 1999. Direct analysis of genes encoding 16S rRNA from complex communities reveals many novel molecular species within the human gut. Appl. Environ. Microbiol., 65: 4799-4807.

Sun, Y.Z., H.L. Yang, R.L. Ma, K. Song and W.Y. Lin. 2011. Molecular analysis of autochthonous microbiota along the digestive tract of juvenile grouper Epinephelus coioides following probiotic Bacillus pumilus administration: Probiont modulates gut microbiota. J. Appl. Microbiol., 110: $1093-1103$. doi:10.1111/j.1365-2672.2011.04967.x

Tamura, K., J. Dudley, M. Nei and S. Kumar. 2007. MEGA4: Molecular evolutionary genetics analysis (MEGA) software version 4.0. Mol. Biol. Evol., 24:1596-1599.

Tewfik, A. 1997. Life history, ecology, fisheries, stock status, and management measures of the queen conch, Strombus gigas. CARICOM Fish. Res. Doc., 19:84-117.

Thaiss, C.A., N. Zmora, M. Levy and E. Elinav. 2016. The microbiome and innate immunity. Nature, 535: 65-74. doi:10.1038/nature18847

Trabal, N., J.M. Mazón-Suástegui, R. Vázquez-Juárez, F. Asencio-Valle, E. Morales-Bojórquez and J. Romero. 2012. Molecular analysis of bacterial microbiota associated with oysters (Crassostrea gigas and Crassostrea corteziensis) in different growth phases at two cultivation sites. Microb. Ecol., 64: 555-569. doi:10.1007/s00248-012-0039-5

Wright, E.S., L.S. Yilmaz and D.R. Noguera. 2012. DECIPHER, a search-based approach to chimera identification for 16S rRNA sequences. Appl. Environ. Microbiol., 78: 717-725. doi:10.1128/AEM.06516-11

Yu, D., G. Wang, J. Xie, S. Guan, Z. Hu and L. Wu. 2007. Activity change of protease and amylase in digestive organs of grouper, Epinephelus coioides. Journal of Zhejiang Ocean University (Natural Science), 26: 246-251.

Yúfera, M. and M.J. Darías. 2007. Changes in the gastrointestinal pH from larvae to adult in Senegal sole (Solea senegalensis). Aquaculture, 267: 94-99. doi:10.1016/j.aquaculture.2007.02.009

Zheng, L., X. Han, H. Chen, W. Lin and X. Yan. 2005. Marine bacteria associated with marine macroorganisms: the potential antimicrobial resources. An. Micobiol., 55: 119-124. 